\title{
Mucosal Immunity in the Female Genital Tract, HIV/AIDS
}

\author{
Juliana Reis Machado, ${ }^{1}$ Marcos Vinícius da Silva, ${ }^{2}$ Camila Lourencini Cavellani, ${ }^{1}$ \\ Marlene Antônia dos Reis, ${ }^{1}$ Maria Luiza Gonçalves dos Reis Monteiro, ${ }^{1}$ \\ Vicente de Paula Antunes Teixeira, ${ }^{1}$ and Rosana Rosa Miranda Corrêa ${ }^{1}$ \\ ${ }^{1}$ Discipline of General Pathology, Nephropathology Service, Federal University of Triangulo Mineiro, Rua Frei Paulino $n^{\circ} 30$, \\ Bairro Abadia, 38025-180 Uberaba, MG, Brazil \\ ${ }^{2}$ Discipline of Immunology, Federal University of Triangulo Mineiro, Rua Frei Paulino n 30, Bairro Abadia, 38025-180 Uberaba, \\ MG, Brazil
}

Correspondence should be addressed to Rosana Rosa Miranda Corrêa; rosana@patge.uftm.edu.br

Received 26 June 2014; Revised 27 August 2014; Accepted 28 August 2014; Published 15 September 2014

Academic Editor: Jerod A. Skyberg

Copyright (C) 2014 Juliana Reis Machado et al. This is an open access article distributed under the Creative Commons Attribution License, which permits unrestricted use, distribution, and reproduction in any medium, provided the original work is properly cited.

\begin{abstract}
Mucosal immunity consists of innate and adaptive immune responses which can be influenced by systemic immunity. Despite having been the subject of intensive studies, it is not fully elucidated what exactly occurs after HIV contact with the female genital tract mucosa. The sexual route is the main route of HIV transmission, with an increased risk of infection in women compared to men. Several characteristics of the female genital tract make it suitable for inoculation, establishment of infection, and systemic spread of the virus, which causes local changes that may favor the development of infections by other pathogens, often called sexually transmitted diseases (STDs). The relationship of these STDs with HIV infection has been widely studied. Here we review the characteristics of mucosal immunity of the female genital tract, its alterations due to HIV/AIDS, and the characteristics of coinfections between HIV/AIDS and the most prevalent STDs.
\end{abstract}

\section{Introduction}

The relationship between STDs and HIV infection has been widely studied. At the end of 2012, approximately 35.13 million people were infected with HIV worldwide. The average prevalence of coinfection between HIV and genital inflammatory diseases is of $16.3 \%$ [1].

\section{Immune Cells of the Female Genital Mucosa}

The immune system of the female genital tract is part of the integrated mucosal immune system, but with some particular characteristics that differentiate the immunity of these regions from the systemic immunity [2-4]. Mucosal immunity is related to its own function, such as maintenance of embryonic development during pregnancy and female reproductive organ functioning during copulation; when in contact with the external environment, the lower portion of the female genital tract is susceptible to various microorganisms. This portion of the female genital tract comprises the vagina and the ectocervix, and it has a commensal microbiota that consists predominantly of Lactobacillus [5]. The upper portion of the female reproductive tract consists of the fallopian tubes, uterus body, and endocervix, which has columnar epithelial cells and is distincted from ectocervix which is part of the lower tract characterized by squamous epithelial cells $[4,6]$. The human female reproductive tract (FRT) is not an immunologically sterile but rather an immunologically active site [7-12].

Many studies have shown the upper FRT to be immunologically viable and responsive. Recent reports have demonstrated that TLRs 7-9 are constitutively expressed in fallopian tubes, uterine endometrium, cervix, and ectocervix, while expression of TLR10 is restricted to the fallopian tubes. NOD1 and NOD2 as well as the signal transducer RICK are detectable in all FRT tissues. Moreover, these receptors are functional, as treatment of FRT tissue cells with ligands 
for TLR and NOD induces production of proinflammatory CXCL8 [13], and those receptors actively participate in immune response to pathogens, as Neisseria gonorrhea and HIV-1 [14].

Mucosal immunity consists of innate and adaptive immune responses that can be influenced by systemic immunity [15] and by hormonal changes during the menstrual cycle. Hormones regulate the immune system throughout the female reproductive tract in a way that favors conditions for sperm migration, fertilization, implantation, and pregnancy $[16,17]$.

Innate immunity includes barriers such as the epithelium, mucus, $\mathrm{pH}$, complement system, and cells of the immune system. The squamous epithelium of vagina and ectocervix recovers the majority of the exposed surface area of the FRT mucosa. It comprises a significant physical barrier to small molecule forms of ingress, such as HIV, due to the thick multilayered structure [18]. In this epithelium, as well as in the more fragile single cell layer epithelium of endocervix, the cells are held together by proteins that form desmosomes, tight junctions, and adherens junctions, which decrease its permeability [19]. For some, this is an impenetrable barrier for agents such as HIV, but Langerhans cells within the squamous layer have been shown to transmit the virus for target cells [20]. In addition, $\mathrm{CD}^{+}$cells infiltrating the epithelium can act as potential target cells to initiate transmission [21].

The mucus is comprised of mucins which form a very thick gel that functions as a physical barrier to pathogens $[22,23]$. Its aqueous part, rich in immunoglobulins and in antimicrobial peptides, is another form of protection [24]. This barrier is important to protect the upper tract from ascending infections.

A major component of the mucus that affects pathogen transmission is the $\mathrm{pH}$. The $\mathrm{pH}$ is maintained by the local presence of commensal bacteria, which keep the $\mathrm{pH}$ acidic through the production of lactic acid and hydrogen peroxide, $\mathrm{H}_{2} \mathrm{O}_{2}$, which has antimicrobicidal activity $[5,25]$. Together, the epithelial cells, mucus, lactic acid produced by commensal bacteria, and proteins of the complement system form a dynamic physiological structure that interacts with microorganisms to prevent infections [15].

Macrophages and dendritic cells (DCs) are important cells which phagocyte and destroy pathogens by acid and enzyme digestion. The macrophages in the female reproductive tract are more concentrated in the endometrium and in the myometrial connective tissue [10]. In the endometrium, they are regulated by estradiol and progesterone [26]. In the vagina, the number of macrophages remains stable throughout the menstrual cycle [10].

DCs are located in the endometrial subepithelial stroma, whereas vaginal DCs are found in the epithelial layer [27]. It was recently demonstrated that uterine epithelial cells secrete soluble mediators to the stroma and that these mediators can induce a tolerogenic phenotype in local dendritic cell populations. This phenotype is characterized by a decrease in the expression of CD83 and CD86 costimulatory molecules and by a decrease in TLR3 and TLR4 stimulation and sensitivity stimulation [28].
NK cells consist of approximately $70 \%$ of leukocytes in the endometrial mucosa and these cells have phenotypic characteristics which are different from NK cells in the blood, as they express markers such as CD9, CD69, and CD94 [29]. Uterine NK cells promote a local inflammatory response through the production of proinflammatory cytokines and chemokines, such as GM-CSF, IL-10, IL-8, and IFN- $\gamma$, thus inducing macrophage activation and generation of cytotoxic T-cells. However, it is believed that the most important role of these cells concerns the defense against viruses, especially herpes [30].

Neutrophils are present throughout the FRT; they are found in larger quantities in the fallopian tubes and progressively decrease from the upper reproductive tract to the vagina [10]. Neutrophil count is relatively constant throughout the menstrual cycle. However, there is a significant increase in neutrophils in the endometrium during menstruation, which is preceded by an increase in IL-8. The presence of neutrophils may serve two purposes in menstruation; firstly, it assists in endometrial tissue destruction via elastase release, which subsequently activates extracellular matrix metalloproteinases; secondly, it increases innate immune defense, since the epithelial barrier is interrupted. Neutrophils express TLRs 1-9 and respond to pathogens through phagocytosis, production of oxidative compounds, and release of antimicrobial peptides. It is known that neutrophils produce protease inhibitors (Trappin-2/Elafin), $\alpha$-defensins known as human neutrophil peptides (HNPs), phospholipases, and cytokines [31].

Innate immune response in the female reproductive system is regulated by cytokines and chemokines. Type I interferons (IFNs) are an important cytokine family involved in female reproductive tract immunity, especially against viruses, and are composed of the following subtypes in humans: IFN $\alpha, \operatorname{IFN} \beta, \operatorname{IFN} \varepsilon, \operatorname{IFN} \omega$, and IFN $\kappa$. IFNs are rapidly induced in the presence of viruses and bacteria $[7,32]$. Although the role of type I IFNs in innate immune response is well defined, the role of hormones in the modulation of these cytokines is still not well elucidated [15]. In most cases, secretion of chemokines is important to attract immune cells to the epithelial surface [8]. Among the cytokines involved, IL-8 and TGF-beta play an important role as they seem to influence the development and function of local immune cells $[7,8,28,33]$. Furthermore, the levels of these cytokines are influenced by hormones during the menstrual cycle, particularly in cervicovaginal region [34]. In acute HIV infections, there is an increase in genital tract cytokine levels, both those with proinflammatory actions like IL-6 and IL12 and those with anti-inflammatory ones, as IL-10 [35]. The elevated levels of local proinflammatory cytokines are related to HIV shedding [36]. IL-1 $\beta$, a proinflammatory cytokine produced by macrophages, and IL-8, a chemokine produced by epithelial cells, macrophages, and other cells, were significantly associated with HIV-RNA in cervicovaginal lavage independent of plasma viral load [37]. Thus, the systemic inflammatory environment is not necessarily related to local genital tract environment and is not associated with HIV shedding [38]. 
Adaptive immunity is a pathogen-specific response after T-cell presentation and stimulation by antigen-presenting cells (APCs) or by B-cells antibodies secretion. This immune response is driven by APCs which, in the female genital tract, include macrophages, dendritic cells, Langerhans cells, and epithelial cells of the cervix and endometrium. The effector components are $\mathrm{CD} 4^{+} \mathrm{T}$-cells as well as the cytokines they secrete, $\mathrm{CD}^{+}$T-cells (cytotoxic effector cells) and immunoglobulins. $\mathrm{CD} 4^{+} \mathrm{T}$-cells are usually subdivided into Th1, Th2, and Treg and Th17 cells, whose development, in general, is directly or indirectly mediated by cytokines during antigen stimulation and which is influenced by hormones [39-43].

Thl cell-mediated immunity involves the destruction of intracellular pathogens by macrophages and cytotoxic effector $\mathrm{CD} 8^{+} \mathrm{T}$-cells activation, which destroy pathogens by recognizing antimicrobial peptide-expressing cells associated with MHCI, hence inducing apoptosis through perforin and granzymes [44]. CD4 ${ }^{+}$T-cells secrete high levels of IFN- $\gamma$, a cytokine that stimulates activation of $\mathrm{CD} 8^{+} \mathrm{T}$-cells, leading to destruction of virus-infected cells $[27,45]$. In female reproductive tract, $\mathrm{CD} 8^{+}$T-cells predominate over $\mathrm{CD} 4^{+} \mathrm{T}$ cells $[46,47]$. During the secretory phase of the cycle, when ovulation and implantation can occur, cellular immunity in the uterus achieves more immune modulation and impact in HIV susceptibility [15, 48-52].

Humoral immunity is characterized by the production of antigen-binding antibodies, thus allowing phagocytosis and inducing antibody-dependent cell-mediated cytotoxicity (ADCC) or eliminating the antigens through the complement system. The immunoglobulins found in the mucosa of the genital tract are, primarily, IgG and IgA; traditionally, IgA is the major immunoglobulin isotype found in secretions [53]. However, a predominance of $\operatorname{IgG}$ in relation to $\operatorname{IgA}$ has been observed in FRT secretions [54, 55]. The amount of immunoglobulins present in cervicovaginal secretions is strongly regulated by hormones, so it varies during the menstrual cycle, with a marked decrease in levels during ovulation [56]. According to Shrier et al. [57], IgA and IgG levels decrease during the follicular phase, reach a minimum amount during ovulation, and increase during the luteal phase. This particular feature may function as a mechanism which facilitates the survival of sperm in the genital mucosa and ensures efficiency of fertilization. However, during this period, alterations in immune functions could impact increased susceptibility or altered response to some infections [57-63].

Although B-cells that synthesize and secrete immunoglobulin are abundant in the endocervix, they are scanty in the vagina, hence suggesting the existence of cellular microenvironments distributed in the genital mucosa. It is possible that humoral immunity in the vagina canal is promoted by local production of immunoglobulins and their transport from the bloodstream to uterine mucosa [54].

As in the intestinal mucosa, IgA is found in the polymeric form (pIgA) in the genital mucosa, and it is transported to the lumen via polymeric immunoglobulin receptor (pIgR) in the secreted form of IgA (S-IgA). PIgR expression in the epithelium of the female genital tract is upregulated by cytokines from activated T-cells, such as IFN- $\gamma$, and also by hormonal changes [54]. Variations in pIgR expression by epithelial cells, caused by female sex hormones, may explain the differences in immunoglobulin levels in cervicovaginal secretions during the menstrual cycle [64]. However, IgG is a monomeric immunoglobulin, and it is probably not transported via pIgR. Nevertheless, IgG is also found in mucous secretions and has a key role in host immune response [65]. The role of IgG in mucosal secretions is controversial, since this isotype can act both as a protective mechanism and as a cytotoxic mediator due to its ability to activate complement proteins and induce antibody-mediated cytotoxicity via polymorphonuclear leukocyte Fc receptor, which would damage mucosal epithelium [54].

Recent studies indicate that antibodies in female reproductive tract from healthy $\mathrm{HIV}(+)$ and $\mathrm{HIV}(-)$ inhibit HIV infection and may play a role in the inhibition of HIV transmission [66]. Several reports have pointed out that IgA in genital mucosal can have an important role in inhibiting HIV transmission [67-70]. Although vaginal secretions of HIV-infected women exhibit IgG directed to a broad range of Env antigens and IgA reactivity to gp41, secretions of women that remain uninfected despite ongoing exposure to HIV-1 contain IgA mostly directed at HIV-1 gp120/gp140. These mucosal HIV-1-specific IgA antibodies could contribute to the protection of these women or be a marker of another protective function [71]. Besides these properties, antibodies in genital mucosa have several functions in the anti-HIV immune response, such as secretory IgA aggregation, Fc-mediated inhibition, neutralization of CD4 T cell infection, lysis of infected cells by NK cells, phagocytosis after antigen presentation, and inhibition following cytokine and chemokine production [72]. Most HIV-1 vaccination strategies aim to induce human HIV-specific antibodies able to inhibit the infection of target cells at the onset of viral transmission; however, inducing such bNAbs by vaccination is likely to be very difficult [73-75]. As HIV transmission at mucosal sites involves specific HIV targets, vaccination should induce an immune response that protects all the different potential mucosal target cells, and strategies to develop local immune responses should therefore be encouraged, leading to a strong and long-lasting response [72].

\section{HIV/AIDS and Cells of the Female Genital Tract}

Sexual transmission is the main route of transmission of HIV [76], with an increased risk of infection in women in comparison to men [76, 77]. Several characteristics of FRT make it susceptible to colonization, to the establishment of infection, and to the systemic spread of the virus, which causes local changes that may eventually facilitate infection by other microorganisms. During the infection establishment, the virus comes into contact with characteristic cells of the female genital tract-such as epithelial cells-and also with resident cells of the innate immune system, adaptive immune system, and mucosal-associated lymphoid tissue (MALT). 
Despite being a subject of intensive studies, it is not fully elucidated what exactly occurs after HIV contact with the mucosa of female genital tract. Nevertheless, it is well established, especially in experimental models using Simian Immunodeficiency Virus (SIV) in Rhesus monkeys, that the infection starts with a small local virus population in the genital tract, which evolves into a marked systemic infection in a few weeks $[78,79]$. Even though, conceptually, the local immune system is the first line of defense against infections, the induction of inflammatory process acts as a viral spread factor, so the activation of cells of the local immune system is a crucial factor for HIV establishment.

It is important to note that, at the cellular level, HIV infection occurs through interaction with receptors and coreceptors present in many cell types. The primary receptor for HIV entrance into a host cell is CD4, and the chemokine receptors CXCR4 and CCR5 are the major coreceptors [80-82]. Two main strains of HIV are described based on coreceptor usage, R5 and X4. Furthermore, several other receptors have been described as essential for HIV internalization and/or transfer between cells [83], such as mannose receptors, DC-SIGN, gal ceramide, heparan sulfate proteoglycans (HSPG), $\alpha 4 \beta 7$ integrin, and gp340 [84-87].

Local epithelial cells play an important role in the development of infection. Changes in epithelial thickness due to hormonal influence during the menstrual cycle, administration of local or systemic, hormonal or nonhormonal contraceptive methods [88-90], and menopause [91, 92] appear to influence the permissiveness to HIV infection, although further studies in humans are needed to determine this influence in vivo.

In general, three main mechanisms are associated with HIV migration through the epithelial cells of the female genital tract: through gaps or microlesions in the epithelial barrier; through transcytosis, which may be mediated by neonatal Fc receptor (FcRn); or through paracellular movement between epithelial cells [50]. Moreover, despite not being primary targets of HIV invasion, epithelial cells of the female genital tract are found to be permissive to HIV infection in vitro, although this phenomenon is still controversial in vivo [93-99].

In vitro studies also indicate that epithelial cells of the genital tract respond differently to R5 and X4 strains of HIV through cytokine production [98, 100-104] and also by driving cytokine production by other immune system cells, especially macrophages, which may interfere with the ability of these cells to recruit CD4 ${ }^{+}$T-cells [98].

Even though epithelial cells do not appear to be able to generate new virions under normal conditions, they can function as a virus transmission mechanism to permissive cells through HIV contact and transfer, thus mediating the systemic spread [105]. Recently infected cells have been detected in the cervical submucosa 3-4 days after primary infection and, in this initial period, the mucus in this region can act as a protective, although relatively inefficient, factor [106]. Furthermore, the presence of HIV directly affects the integrity of the epithelial barrier in the female genital tract mucosa, allowing for translocation of pathogens [107].
Dendritic cells (DCs) are believed to be the primary target of HIV infection, spreading the infection to the associated lymph nodes and acting as a disseminator [108-111]. Moreover, these cells can invaginate into the epithelium towards the lumen, capturing HIV and allowing its transmission to the submucosal cells, that is, phagocytes and $\mathrm{CD}^{+} \mathrm{T}$ cells [109]. However, these cells also act directing anti-HIV adaptive immune response and priming $\mathrm{CD} 4^{+}$and $\mathrm{CD} 8^{+} \mathrm{T}$ cells. Viral receptors present on DCs, such as TLR- 8 and DCSIGN, have been associated with the spread of HIV to CD $4^{+}$ T-cells [112]. On the other hand, $\alpha$-defensins 1-3 production by DCs is associated with a slower progression of HIV infection [113]. Moreover, several studies have pointed to an important interaction of HIV with a specific type of dendritic cells called Langerhans cells (LC), which are characterized by the expression of Langerin and by being found mainly in mucosae; they can get infected with HIV and act as a viral inhibitor [114], although they seem to act more as a mechanism of capture and transport of viruses to $\mathrm{CD} 4^{+} \mathrm{T}$ cells [21, 115-117]. HIV infection leads to a reduction in LC density in the female genital mucosa [118], and the systemic activity of HIV infection also affects the population of LCs in the vagina, which decreases in the presence of detectable HIV-RNA but is not decreased in the absence of detectable plasma levels of HIV-RNA [119].

Among other cellular components of innate immunity in the female genital tract mucosa, macrophages participate actively in HIV infection; they are effector cells and one of the main targets of this virus. HIV infection leads to changes in macrophages both systemically and in the female genital tract mucosa. In general, HIV-infected monocytes and macrophages have several impaired or modulated functions which promote viral persistence or delay the development of the adaptive immune system, for instance, impaired antigenpresenting ability [120], impaired T-cell-activation ability $[121,122]$, impaired ability to engulf and destroy intracellular microorganisms [123-126], decreasing expression of surface molecules, such as CD36 [127], decreasing expression of Fc receptors [128, 129], impaired TLR signaling response [130], and increased susceptibility to phagocytosis [131].

Several studies have reported contradictory outcomes on the role of macrophages as cells promoting virus spread through vaginal mucosa transmission, especially when compared to in vitro studies with HIV-infected cells and SIV infection models. If, on the one hand, the authors indicate that the initial establishment of HIV infection is sustained by macrophages [132-134], infection of Rhesus monkeys with SIV failed to show this relationship, so it is required to determine the actual role of these cells as protagonists in the establishment of the infection [135]. However, despite such discrepancies, these cells have been continuously implicated as carriers of infection to $\mathrm{CD} 4^{+} \mathrm{T}$-cells, to local cells, and to associated lymphoid tissues $[112,136]$. A feature that may facilitate this process is the increased expression of CD4, CXCR4, and CCR5 receptors associated with HIV infection in vaginal macrophages rather than with other mucosae [137, 138].

On the other hand, studies have shown that these cells produce cytokines and chemokines that act as promoters 
of intense inflammatory infiltration in the mucosal lining of the female genital tract [139]. This inflammation plays a paradoxical role; it is, at the same time, an effector mechanism of antiviral immunity and one of the main promoters of the establishment of HIV infection, allowing the virus to multiplicate quickly and to infect new susceptible cells [139]. Indeed, enhanced HIV-1 replication in ex vivo ectocervical tissues from postmenopausal women correlates with increased inflammatory responses [140]. In this context, there is a marked induction of CCL2, CCL3, CCL4, CCL5, CXCL8, and CXCL10 after infection with SIV, as well as a systemic increase of CCL2, CXCL8, and CXCL10 in humans, concurrently with viremia peak after infection with HIV [141]. Once HIV is primarily concentrated in mucosae, they probably play a major role in the production of these mediators $[78,142]$. These chemokines have a direct effect on the recruitment of new macrophages and $\mathrm{CD} 4{ }^{+} \mathrm{T}$-cellstargets of viral spread [79, 142-144]. Even though the local production of chemokines attracts more HIV target cells, chemokines may act as competitors for binding CCR5 and CXCR4 receptors $[145,146]$.

HIV interference in the macrophages functions, particularly in those related to viral persistence, is mainly mediated by Nef, which is a protein capable of modulating the surface receptors expression, interfering with intracellular signaling pathways, increasing the production of cytokines and chemokines, and changing phagocytic and autophagic capacity [147-152].

Although the relationship of HIV with the number of neutrophils and their functional impact is not well known and investigated, studies have pointed out that neutrophils are increased in the female genital tract in chronic infection due to the local increase of IL- $1 \beta$, TNF- $\alpha$, IL- 8 , IL- 6 , and IL10 [153]. It still needs to be clarified whether this increase is, to some extent, a mechanism of cell control or recruitment for the perpetuation of infection. In a more general context, HIV infection has an impact on the formation of neutrophils in the bone marrow [154] and it reduces the expression of CD13 and CD16 $[155,156]$. These cells have recently been implicated in the suppression of $\mathrm{CD} 4{ }^{+} \mathrm{T}$-cells via $\mathrm{PD}-\mathrm{L} 1 / \mathrm{PD}-$ 1 [157] and in antibody-dependent cell death [158]. Moreover, hypochlorite/hypochlorous acid $(\mathrm{HOCl})$ produced via myeloperoxidase (MPO) secretion to the outside of the cells has emerged as a mechanism of HIV destruction [159, 160]. On the other hand, HIV-1-infected peripheral blood mononuclear cells enhance neutrophil survival and HLADR expression via increased production of GM-CSF [161]. Recently, Neutrophil extracellular traps (NETs) have been described as a host defense response to human immunodeficiency virus-1 preventing virus spreading [162]. The recruitment of neutrophils and mononuclear phagocytes to an infectious site brings into play HNPs (human neutrophil peptide) and further increases in LL-37. Despite significant HIV inhibitory activity, cervicovaginal levels of $\alpha$-defensins 1-3 (HNPs 1-3) and LL-37 were associated with increased HIV acquisition, perhaps due to their association with bacterial sexually transmitted infections [163]. On the other hand, human neutrophil $\alpha$-defensin 4 inhibits HIV-1 infection in vitro [106].
Despite the clear involvement of NK cells in the immune response against the virus, classical studies have demonstrated that HIV-positive individuals have a poor response of these cells [164-166]. NK cells fail to degranulate and to produce IFN- $\gamma$, leading to poor response against bacteria [167], to human papillomavirus (HPV) $[168,169]$, and to an impaired antibody-dependent cell-mediated cytotoxicity associated with HIV infection progression [170]. Studies suggest that, at least in part, these defects can be related to functional depletion of NK cells, with possible involvement of PD-1 and TIM-3 [171, 172]. As previously discussed, female genital tract NK cells express different phenotypic markers from NK cells in the bloodstream, such as CD9, CD69 and CD94 [29]. It seems that uterine NK cells can inhibit the infection of target cells by HIV X4 but not R5 strains via the secretion of CXCL12 [29]. Functional modulation of NK cells has been correlated with resistance to HIV infection in highly exposed HIV-seronegative (HESN) [173]. Killer immunoglobulin-like receptors (KIRs) regulate natural killer (NK) cells in a human leukocyte antigen (HLA) - in a dependent manner, and KIR3DL1/S1 and KIR2DL2/DL3 loci have been linked to resistance to HIV infection $[174,175]$. Also, KIR/HLA interactions may influence resistence versus susceptibility to virus transmission [175-179].

Among the cells in the mucosa of the genital tract, $\mathrm{CD} 4^{+} \mathrm{T}$-cells seem to be the most important target for the establishment of a successful HIV infection [180]. Several studies have demonstrated that the infection starts with a small number of $\mathrm{CD}^{+}$T-cells infected with HIV that multiply before systemic viremia is established $[181,182]$. As aforementioned, this key role is closely related to the presence of receptors and coreceptors that mediate the infection of these and other cells of the immune system. In fact, studies in humans have demonstrated that HIV infects, extremely effectively, $\mathrm{CD} 4^{+} \mathrm{T}$-cells in several areas of the female genital tract, especially vagina, ectocervix, and endocervix [117].

Classic studies had already indicated that, besides the reduced $\mathrm{CD} 4^{+} \mathrm{T}$ cell count, several dysfunctions were observed in $\mathrm{CD}^{+}{ }^{+}$T-cells from HIV-positive individuals, including an impaired response to polyclonal stimuli or recall antigens, reduced production of IFN- $\gamma$ and IL-2, deficient TCR signaling pathways, and a proliferative capacity decrease [183-187].

Interestingly, studies have shown that different subtypes of $\mathrm{CD} 4^{+}$T-cells have different levels of susceptibility to HIV infection [117]. For instance, the T-cell subset expressing the integrin alpha4beta7-a mucosal homing receptor-is highly susceptible to HIV-1 infection [188]. Furthermore, most HIV infections through sexual intercourse apparently involve viruses that use CCR5, that is, R5 tropic strains, which implies that they preferentially infect cells that express this receptor [189-191]. Nevertheless, there is a significant population of CD4 T-cells expressing CXCR4 in the mucosa of the female genital tract, so its importance in the acquisition and development of infection needs to be clarified [192]. Interestingly, postmenopausal women show an increase in $\mathrm{CD}^{+} \mathrm{CCR}^{+}{ }^{+}$-cells in the gastrointestinal tract, which may lead to an increased susceptibility to HIV infection, even 
though the exact mechanism for this increase also needs to be elucidated [193].

Sexual transmission of human immunodeficiency virus type 1 (HIV-1) most often results from a productive infection by a single transmitted/founder (T/F) virus that rises to a productive systemic infection after approximately two weeks [194-198]. Recent reports have pointed out that T/F viruses utilize the CCR5 coreceptor for entry and replicate efficiently in cultures of activated primary $\mathrm{T}$ lymphocytes and replicate in monocyte-derived macrophages (MDM) [199]. Also, it seems that transmitted/founder and chronic HIV-1 are distinguished by differential utilization of CCR5-with $\mathrm{T} / \mathrm{F}$ viruses presenting proteins with higher CCR affinity [200-202], favoring preferential sexual transmission of R5 strain.

Recent findings have supported the impression that, although HIV is virtually able to infect any $\mathrm{CD} 4^{+} \mathrm{T}$ cell, there is a preference for the infection of activated lymphocytes [181]. T-cell profiles with a more inflammatory nature, such as Thl7, are preferably infected and allow for greater viral replication, resulting in depletion of these cells in HIVinfected individuals compared with healthy individuals and showing a proportional decrease in viral load [203-206]. Moreover, it was demonstrated that a subset of activated cervical CD $4^{+}$T-cells that expresses $\alpha 4 \beta 7$, CCR5, IL-17A, and IFN- $\gamma$ preferentially binds HIV-1 gp120 in vitro, and these cells are almost entirely depleted from the cervix in vivo during HIV infection. The presence of multiple susceptibility markers in a subset of $\mathrm{CD} 4^{+}$T-cells in the genital tract suggests that these cells may play a key role as HIV targets during sexual transmission [192].

Along with Th17 cells, IL-22-producing T-cells and Th22 cells were dramatically depleted during chronic HIV infection, concomitant with epithelial integrity impairment and increased microbial translocation [207]. Furthermore, circulating Th22 cells expressed a higher level of the HIV coreceptor/binding molecules CCR5 and $\alpha 4 \beta 7$ than $\mathrm{CD} 4^{+} \mathrm{T}$ cell subsets in HIV-uninfected participants, but this was not the case after HIV infection [207]. The role of the differential infection of these T-cell profiles in HIV susceptibility and in other associated infections needs to be better clarified.

A recent review brought an interesting thought that could help explain the low infection-to-exposure ratio and the selection of the founder strain after sexual exposure to HIV [208]. The founder strain is a single virus variant that usually initiates the infection with HIV, despite the presence of thousands of genetically diverse viral strains in the transmitting partner $[190,209,210]$. Comparing this situation with the transmission dynamics of infectious diseases, where differences in the ability of individuals to spread the infection may set whether an outbreak will turn into an epidemic [211], and based on evidence from molecular biology and virology, the authors suggest that heterogeneity among $\mathrm{CD} 4^{+} \mathrm{T}$-cells could yield wide variation in the capability of individual cells of becoming infected and of transmitting HIV to other cells [208]. Using an epidemiological framework, they suggest that such heterogeneity among $\mathrm{CD} 4^{+} \mathrm{T}$ may play a critical role in the establishment and spread of HIV in the genital mucosa after sexual exposure [208]. Although there are no in vivo evidence that this phenomenon occurs (despite differences in subsets $\mathrm{CD} 4^{+} \mathrm{T}$-cells in susceptibility to HIV infection, as discussed above), it may explain why some women might be more susceptible to HIV sexual transmission than others.

After the establishment of HIV infection in the genital mucosa, the presence of cytotoxic T-cells is detected not only in this region but also in mucous membranes in general. Nevertheless, as previously suggested, the response of these cells is "too little and too late" to contain viral replication and dissemination [212]. A previous report showed that proinflammatory cytokines in the female genital tract may promote HIV replication and shedding. These cytokines were associated with increased levels of HIV-specific CD8 effector cells in the genital mucosa but these were not able to control genital HIV shedding [213].

As the infection progresses, $\mathrm{CD} 8^{+} \mathrm{T}$-cells can be detected in the genital tract mucosa of HIV-positive women [213215]. Although, in general, $\mathrm{CD} 8^{+} \mathrm{T}$-cells from healthy individuals are polyfunctional, the ability of cervical $\mathrm{CD}^{+} \mathrm{T}$ cells to exhibit polyfunctional responses (ability to produce 2 or more cytokines) following HIV stimulation is inversely associated with plasma viral load and positively associated with blood CD4 counts, suggesting that clinical status had an impact on the functionality of HIV-specific T-cells in the mucosa and that cervical T-cells are largely monofunctional. Furthermore, polyfunctional T-cells in the cervix of women with high blood CD4 count and low plasma viral load do not protect from HIV genital shedding [216].

\section{Immunity of Female Genital Mucosa, HIV/AIDS and STDs}

4.1. Bacterial Vaginosis and HIV/AIDS. Bacterial vaginosis is a condition caused by an alteration in the genital tract flora in which lactobacilli are predominantly replaced by anaerobic bacteria, including Gardnerella vaginalis, Mycoplasma hominis, and Atopobium vaginae as well as species of Prevotella, Mobiluncus, and Peptostreptococcus [217]. Considered the most common cause of vaginitis, bacterial vaginosis is associated with urinary tract infections, pelvic inflammatory disease, preterm labor, and also an increased risk of HIV infection [218, 219]. The incidence of bacterial vaginosis ranges from $8 \%$ to $23 \%$ of women of reproductive age, whereas the incidence rate is as high as approximately $50 \%$ of HIV-infected women [220, 221].

The lactobacilli present in a healthy vaginal microbiome, especially Lactobacillus acidophilus, predominantly produce hydrogen peroxide $\left(\mathrm{H}_{2} \mathrm{O}_{2}\right)$, which is responsible for maintaining a low vaginal $\mathrm{pH}$ and for inhibiting microbial growth, including the causative agents of bacterial vaginosis [222]. $\mathrm{H}_{2} \mathrm{O}_{2}$ also has a virucidal effect on HIV-1 [223]; it inhibits viral adhesion and replication, as well as $\mathrm{CD}^{+} \mathrm{T}$ cell activation, therefore reducing the number of HIV target cells in the vagina [224].

Like other sexually transmitted pathogens, bacterial vaginosis has been associated with increased acquisition and transmission of HIV in women [221, 225]. Studies have shown that an increased HIV shedding is found in vaginal secretions 
of women with bacterial vaginosis or with low levels of lactobacilli $[226,227]$ and also that these secretions/fluids are able to stimulate HIV expression in vitro [164].

The immunosuppression caused by HIV can increase the frequency or severity of bacterial vaginosis. The disease is more persistent among HIV-infected women with lower CD4 cell counts who are also more likely to develop more severe symptoms of bacterial vaginosis [220]. Analyses of vaginal secretions of HIV-seropositive women demonstrated an inverse correlation between viral load and lactobacillus species and a positive correlation between bacterial vaginosis and Mycoplasma hominis [228].

Previous studies suggested that anaerobic bacterial growth and increased $\mathrm{pH}$ observed in the establishment of bacterial vaginosis profile inhibit the concomitant growth of Candida in these patients [229]. Bacterial vaginosis also influences the development of cervical intraepithelial neoplasia, possibly due to the production of nitrosamines that can cause DNA damage and to the change in the profile of cytokines that decrease the ability of the immune system to eliminate HPV infection [230]. Furthermore, HIV infection itself alters the vaginal immune response and the cytokine profile, further increasing the etiologic mechanisms between this association of bacterial vaginosis and precancerous lesions [231].

4.2. Candidiasis and HIV/AIDS. Candida albicans, the main causative agent of vaginal candidiasis, colonizes the genital tract of $75 \%$ of women of reproductive age, regardless of sexual activity [232], and about $5 \%$ to $8 \%$ of these women experience recurrent infection [233].

HIV infection has been considered one of the risk factors for the development of symptomatic Candida infection, together with pregnancy, uncontrolled diabetes mellitus, and use of corticosteroids, antibiotics, or oral contraceptive pills with high estrogen concentrations [234].

In the HIV/AIDS scenario, mucosal candidiasis is one of the oldest and most common opportunistic infections in HIV-positive women $[235,236]$. Although it is not considered a syndrome-defining illness, vaginal candidiasis is classified by the centers for disease control and prevention for human immunodeficiency virus as a condition whose course or management may be altered by HIV infection [237-240].

Although a higher frequency of vulvovaginitis in women infected with HIV is not yet fully established, most studies show a higher prevalence of vaginal candidiasis with a higher recurrence risk in HIV-infected women than in uninfected women $[236,239,241-243]$. Other authors also claim that the increased rates of Candida colonization are associated with decreased $\mathrm{CD} 4^{+} \mathrm{T}$ cell count, especially below 200 cells $/ \mathrm{mm}^{3}$ $[241,244,245]$, indicative of systemic immune failure.

HIV infection is clearly involved in changes in the normal vaginal flora that favor the development of local infections and sexually transmitted diseases, which, in addition to increasing local replication of the virus, potentially play a role in the sexual transmission of HIV $[246,247]$. This is because $\mathrm{HIV}$ infection reduces the number of $\mathrm{CD} 4^{+}$T-cells and leads to increased chemokine levels in the vaginal mucosa $[242,248]$, whereas vaginal infections increase susceptibility to virus infection due to a lower production of hydrogen peroxide by lactobacilli and to the disruption of the normal epithelial barrier [249]. On the other hand, as previously discussed, inflammatory stimuli and consequent immune activation could act as a direct mechanism that attracts target cells and favors HIV replication [139, 140].

The symptoms of vaginal candidiasis often occur at an earlier stage in the course of HIV infection, and they are associated with the reduction of the normal vaginal flora and $\mathrm{pH}$, favoring germ tube formation in yeast cells and increased inflammation and virulence [250], even though the severity of the infection is not increased in HIV-positive women. Furthermore, after vaginal infection treatment, the recurrence time is higher in HIV-positive patients, and the time interval correlates closely with the severity of immunosuppression [251].

4.3. Trichomonas Vaginalis and HIV/AIDS. Trichomoniasis, which is caused by the flagellated protozoan Trichomonas vaginalis, is one of the most common sexually transmitted diseases (STDs) in HIV-infected women and uninfected women. Epidemiological studies show prevalence rates ranging from $6 \%$ to $27 \%$ in the group of HIV-positive women, with values reaching $36 \%$ in reinfection episodes by the protozoan $[220,252,253]$.

This STD is associated with pregnancy complications such as premature rupture of membranes and premature birth, infertility, and cervical cancer $[254,255]$. The fact that $\mathrm{HIV}$ infection risk is 2-9 times higher in the presence of a sexually transmitted disease [256] has highlighted trichomoniasis as an important disease in the scenario of HIV/AIDS infection and transmission [257], and effective treatment of this disease is an important strategy for HIV prevention.

Trichomoniasis is considered a risk factor for HIV transmission and infection because it stimulates an intense inflammatory response of the vaginal epithelium and ectocervix with evidence of punctate hemorrhages, causing disruptions of the urogenital epithelium that act as virus gateways [258].

Trichomonas infection in HIV-positive women is associated with an increase in genital shedding of HIV [259] and, similarly to what happens with vaginal candidiasis in HIVinfected women, the prevalence of trichomoniasis increases with the decline in immune function measured by $\mathrm{CD} 4^{+} \mathrm{T}$ cell count and nonadherence to HAART [260].

4.4. Genital Herpes and HIV/AIDS. Genital herpes, caused by Herpes simplex type-2 (HSV-2), is a chronic sexually transmitted disease of high global burden that causes genital ulcers [261]. The incidence rates of genital herpes in HIVpositive women have been reported to vary between $11 \%$ and $50 \%$; however, more than $80 \%$ of these patients are asymptomatic [262-264].

Considered one of the greatest risk factors for HIV acquisition in developing countries, HSV-2 seroprevalence rates reach $90-95 \%$ in $\mathrm{HIV}$-infected women [265], and the frequency of reactivation of herpes simplex type-2 is also 24 times higher in this population than in uninfected women $[266,267]$. 
As in diseases such as syphilis and chancroid, HSV-2 is particularly important in the acquisition and transmission of HIV since it allows for the disruption of mucosa causing inflammation and the development of ulcers, which facilitates HIV entry [268].

Coinfection between HIV and HSV-2 and the bidirectional synergistic relationship between them increase the spread of viruses causing AIDS and genital herpes. HIV infection increases genital shedding and the frequency of herpes reactivation, which, in turn, increases the concentrations of HIV in the plasma and in genital secretions and the risk of HIV transmission and disease progression [269, 270]. On the other hand, coinfection of CD4 T-cells by HIV and HSV results in a rapid unidirectional replication of HIV, whereas the acquisition, reactivation, and shedding of $\mathrm{HSV}-2$ are facilitated by disturbances in the vaginal flora resulting in bacterial vaginosis $[271,272]$.

The frequency and severity of HSV-2 recurrences are enhanced by the immunodeficiency caused by HIV infection. Even though treatment with high potency antiretroviral therapy reduces the frequency and severity of genital herpes, HIV-seropositive women have a higher number of genital ulcers and increased viral shedding than uninfected women $[273,274]$. In general, genital herpes ulcers are more generalized, painful, persistent, and recurrent in HIV-positive patients [275].

4.5. Pelvic Inflammatory Disease (PID) and HIV/AIDS. Pelvic inflammatory disease (PID) comprises a spectrum of inflammatory disorders of the female upper genital tract that are caused by microorganisms arising from the uterine cervix [276]. The signs and symptoms are nonspecific and varied, and $70-80 \%$ of the cases are asymptomatic [277]. Classically associated infectious agents include Chlamydia trachomatis and Neisseria gonorrhoeae.

Chlamydia is the most common sexually transmitted disease (STD) in the world, more common than syphilis and gonorrhea [278]. It is an obligate intracellular bacterium that causes polymorphonuclear infiltration in the epithelium at the onset of infection, followed by subepithelial mononuclear infiltration with tissue injury and scarring, which leads to the following frequent sequelae, infertility, ectopic pregnancy [279], and chronic pelvic pain.

This bacterium has several factors involved in cytokine production through the stimulation of TLRs [280], HSP60 [281], and chlamydial CpG-DNA [282]. Along with TNF- $\alpha$, IL-1 (a cytokine produced by infected epithelial cells) induces the production of IL- 8 by endothelial cells, epithelial cells, and monocytes; the latter are the major neutrophil chemotactic factor [279]. Furthermore, IL-1 binding to its respective receptor initiates a mitogen-activated protein (MAP) kinases pathway, such as the p38 pathway, which is also activated by binding to TLRs and to the TNF receptor, and which will promote the transcription of adhesion molecules [283].

The recruitment of leukocytes in genital inflammatory diseases such as infections caused by C. trachomatis and $N$. gonorrhoeae enhances the acquisition and transmission of HIV [284], with an increase in the concentration of HIV-1 in the genital secretion. Similarly, the significant epithelial lesion in cases of Chlamydia infection is definitely a contributing factor in coinfection [285].

Moreover, proinflammatory cytokines generally stimulate replication of $\mathrm{HIV}$ virus in the genital tract, as they activate nuclear factor $\kappa \mathrm{B}$ as well as recruit and activate leukocytes, which are the targets of the virus [153]. Cytokines such as TNF- $\alpha$ can permeabilize the epithelial intercellular junctions, facilitating HIV infection [107]. The exact definition of the role of each inflammatory mediator is still divergent in the literature, probably due to the difference in the cohort studied and to the various factors involved.

Baeten et al. recently revealed a correlation between high levels of HIV-1 RNA in the genital secretion and an increased risk of transmission, regardless of the serum levels of HIV. Genital shedding of HIV1 can happen even in women with undetectable serum levels of HIV-1 [286], an occurrence which may be explained by the infections of the lower genital tract [38]. It is known that HAART (highly active antiretroviral therapy) reduces HIV-1 concentration in vaginal secretions [287] and in the plasma, as well as the risk of transmission [288, 289], but it does not eliminate it. An approach that integrates both treatments, HAART and a specific approach for each STD, is certainly more effective in controlling the disease. Nonetheless, because of insufficient monitoring or absence of symptoms in patients with AIDS, the major challenge is allowing for the early diagnosis of these STDs.

Diseases with genital discharge, such as gonorrhea, are particularly likely to increase HIV release in semen and cervicovaginal secretions [290]. Previous reports showed that gonorrhea is the sexually transmitted disease most associated with HIV, with an increment in the risk of HIV infection [248, 291-293].

N. gonorrhoeae activates TLR2 on CD4 T-cells, thus facilitating the infection, even at an earlier phase of the viral cycle, immediately after infection [292]. Furthermore, the bacterium increases the ability of the virus to infect dendritic cells, which, in turn, can introduce the virus to other susceptible cells [293].

4.6. Human Papillomavirus (HPV) and HIV/AIDS. There are about 40 genotypes of HPV capable of infecting the genital tract, and they are divided into two groups based on their oncogenic potential: low risk (causing genital warts/warts) and high risk [294], causing cervical cancer. Cervical cancer is the second most common cancer in women worldwide [295] and, in almost all cases, it is associated with persistent infection by high risk HPV types, especially 16 and 18 [296]. In turn, infection by HPV, a DNA virus, is the most common sexually transmitted disease in the world [297], and it causes anogenital lesions that are more prevalent in women. High risk HPVs are also associated with vulvar, vaginal, penile, anal, and oropharyngeal cancers [298]. Sexually active men seem to be a reservoir of high risk HPV subtypes [299].

The virus infects basal epithelial cells through microabrasions on the epithelial surface. The oncogenesis depends on the integration of the viral episome into the DNA of 
the epithelial cell [300] and on the activity of the viral oncoproteins E6 and E7 [301]. Both CD $4^{+}$and CD8 ${ }^{+}$T-cells are capable of recognizing these proteins. E6 is responsible for the degradation of proapoptotic proteins such as p53 [302], Mantovani and Banks [303]; whereas E7 promotes cell entry into the S phase of the cell cycle [304], and it integrates with the tumor suppressor protein $\mathrm{pRb}$ [305]. There are few copies of the viral genome in the basal layer [304]; the production of infective particles occurs only in the more differentiated layers of the epithelium [306].

Seroconversion occurs in $60 \%$ of immunocompetent women, but antibody production during infection is not able to prevent reinfections, probably due to the low titers [307].

The cellular immune response against viral proteins in immunocompetent individuals is responsible for suppressing the infection in $90 \%$ of patients in two years [308], with regression of premalignant and low grade squamous intraepithelial lesions, even without therapeutic interventions. In individuals with HIV/AIDS, this clearance is impaired [309].

The development of HPV-16 associated lesions, the most common high risk HPV subtype and that has early progression [302], is connected with the ineffective immune response against HPV-16 E6 and E7 [310]. The immune status also appears to influence the prevalence of HPV-18, which is between $15 \%$ and $18 \%$ in immunocompetent women and approximately $80 \%$ in immunocompromised women [300].

In persistent HPV infection there is no significant local inflammatory reaction, and therefore there is no significant increase in the risk of HIV acquisition/transmission in the genital tract [311]. Nonetheless, in nonpersistent infections, there is an increased number of T-cells in the infected cervix [312]. As with the majority of intracellular viruses, these cells are necessary to overcome the infection, and, because they are HIV targets, there is a transient increase in the risk of $\mathrm{HIV}$ infection during the regression process of HPV lesions [313]. Another potential mechanism is that the E7 protein of HPV-16 decreases the expression of E-cadherin, an epithelial adhesion molecule, hence increasing the permeability of the epithelium to HIV [314]. The meta-analysis performed by Houlihan et al. indicated a twofold increase in the risk of HIV infection when there was prior infection by any HPV genotype [294].

Furthermore, HIV coinfection increases the detection, persistence, and severity of HPV lesions [315]. This is caused by immunosuppression, which generates persistent HPV infection, infection by subtypes that are more susceptible to cause carcinomas, simultaneous infection by several subtypes, reactivations, and infection by HPV in several sites in the anogenital region [302]. In HIV-infected women, cervical cancer behaves more aggressively, with more recurrences and a worse prognosis, as well as being somewhat responsive to traditional therapies [316].

\section{Conclusion}

The female genital tract mucosa has an inflammatory environment somewhat independent from the systemic environment concerning HIV shedding. Several studies showed genital HIV shedding in women with undetectable plasma viral load. This occurrence is due to local immune particularities and mainly because of coinfections by other sexually transmitted diseases. There is a bidirectional synergistic relationship in which HIV infection favors the development of local infections and these diseases increase local replication of the virus.

Certainly, an adequate approach to control this process would be the combination of HAART and the specific treatment of each sexually transmitted disease. The great challenge is to diagnose these conditions, as patients with AIDS can be assintomatic. Therefore, rigorous monitoring is required.

\section{Conflict of Interests}

The authors declare that they have no conflict of interests.

\section{Authors' Contribution}

J. R. Machado and M. V. Silva have contributed equally to this work.

\section{Acknowledgments}

This study was conducted at Nephropathology Service in General Pathology Division of Triangulo Mineiro Federal University, Uberaba, Minas Gerais, Brazil, with grants from Conselho Nacional de Desenvolvimento Científico e Tecnológico $(\mathrm{CNPq})$, Coordenação de Aperfeiçoamento de Pessoal de nível Superior (CAPES), Fundação de Amparo à Pesquisa do Estado de Minas Gerais (FAPEMIG), and Fundação de Ensino e Pesquisa de Uberaba (FUNEPU).

\section{References}

[1] S. C. Kalichman, J. Pellowski, and C. Turner, "Prevalence of sexually transmitted co-infections in people living with HIV/AIDS: systematic review with implications for using HIV treatments for prevention," Sexually Transmitted Infections, vol. 87, no. 3, pp. 183-190, 2011.

[2] J. Mestecky and P. N. Fultz, "Mucosal immune system of the human genital tract," Journal of Infectious Diseases, vol. 179, supplement 3, pp. S470-S474, 1999.

[3] J. Pudney, A. J. Quayle, and D. J. Anderson, "Immunological microenvironments in the human vagina and cervix: mediators of cellular immunity are concentrated in the cervical transformation zone," Biology of Reproduction, vol. 73, no. 6, pp. 12531263, 2005.

[4] Y. A. R. Lima and M. F. C. Alves, "O sistema imune da mucosa do trato genital feminino eo impacto das doenças sexualmente transmissíveis," Revista de Patologia Tropical, vol. 37, no. 4, pp. 295-309, 2008.

[5] R. Martin, N. Soberon, F. Vazquez, and J. E. Suarez, "Vaginal microbiota: composition, protective role, associated pathologies, and therapeutic perspectives," Enfermedades Infecciosas y Microbiología Clínica, vol. 26, no. 3, pp. 160-167, 2008.

[6] A. J. Quayle, "The innate and early immune response to pathogen challenge in the female genital tract and the pivotal 
role of epithelial cells," Journal of Reproductive Immunology, vol. 57, no. 1-2, pp. 61-79, 2002.

[7] T. M. Schaefer, J. V. Fahey, J. A. Wright, and C. R. Wira, "Innate immunity in the human female reproductive tract: antiviral response of uterine epithelial cells to the TLR3 agonist poly(I:C)," Journal of Immunology, vol. 174, no. 2, pp. 992-1002, 2005.

[8] J. V. Fahey, T. M. Schaefer, J. Y. Channon, and C. R. Wira, "Secretion of cytokines and chemokines by polarized human epithelial cells from the female reproductive tract," Human Reproduction, vol. 20, no. 6, pp. 1439-1446, 2005.

[9] M. Ghosh, T. M. Schaefer, J. V. Fahey, J. A. Wright, and C. R. Wira, "Antiviral responses of human Fallopian tube epithelial cells to toll-like receptor 3 agonist poly(I:C)," Fertility and Sterility, vol. 89, supplement, no. 5, pp. 1497-1506, 2008.

[10] C. R. Wira, J. V. Fahey, C. L. Sentman, P. A. Pioli, and L. Shen, "Innate and adaptive immunity in female genital tract: cellular responses and interactions," Immunological Reviews, vol. 206, no. 1, pp. 306-335, 2005.

[11] C. R. Wira, K. S. Grant-Tschudy, and M. A. Crane-Godreau, "Epithelial cells in the female reproductive tract: a central role as sentinels of immune protection," The American Journal of Reproductive Immunology, vol. 53, no. 2, pp. 65-76, 2005.

[12] C. R. Wira, R. M. Rossoll, and R. C. Young, "Polarized uterine epithelial cells preferentially present antigen at the basolateral surface: role of stromal cells in regulating class II-mediated epithelial cell antigen presentation," Journal of Immunology, vol. 175, no. 3, pp. 1795-1804, 2005.

[13] K. M. Hart, A. J. Murphy, K. T. Barrett, C. R. Wira, P. M. Guyre, and P. A. Pioli, "Functional expression of pattern recognition receptors in tissues of the human female reproductive tract," Journal of Reproductive Immunology, vol. 80, no. 1-2, pp. 33-40, 2009.

[14] M. Ghosh, Z. Shen, J. V. Fahey et al., "Pathogen recognition in the human female reproductive tract: expression of intracellular cytosolic sensors NOD1, NOD2, RIG-1, and MDA5 and response to HIV-1 and Neisseria gonorrhea," The American Journal of Reproductive Immunology, vol. 69, no. 1, pp. 41-51, 2013.

[15] D. K. Hickey, M. V. Patel, J. V. Fahey, and C. R. Wira, "Innate and adaptive immunity at mucosal surfaces of the female reproductive tract: stratification and integration of immune protection against the transmission of sexually transmitted infections," Journal of Reproductive Immunology, vol. 88, no. 2, pp. 185-194, 2011.

[16] G. Mor and I. Cardenas, "The immune system in pregnancy: a unique complexity," The American Journal of Reproductive Immunology, vol. 63, no. 6, pp. 425-433, 2010.

[17] C. R. Wira, J. V. Fahey, M. Ghosh, M. V. Patel, D. K. Hickey, and D. O. Ochiel, "Sex hormone regulation of innate immunity in the female reproductive tract: the role of epithelial cells in balancing reproductive potential with protection against sexually transmitted pathogens," The American Journal of Reproductive Immunology, vol. 63, no. 6, pp. 544-565, 2010.

[18] R. J. Shattock and J. P. Moore, "Inhibiting sexual transmission of HIV-1 infection," Nature Reviews Microbiology, vol. 1, no. 1, pp. 25-34, 2003.

[19] A. M. Carias, S. McCoombe, M. McRaven et al., "Defining the interaction of HIV-1 with the mucosal barriers of the female reproductive tract," Journal of Virology, vol. 87, no. 21, pp. 1138811400, 2013.
[20] C. J. Miller and R. J. Shattock, “Target cells in vaginal HIV transmission," Microbes and Infection, vol. 5, no. 1, pp. 59-67, 2003.

[21] M. Zaitseva, A. Blauvelt, S. Lee et al., "Expression and function of CCR5 and CXCR4 on human Langerhans cells and macrophages: implications for HIV primary infection," Nature Medicine, vol. 3, no. 12, pp. 1369-1375, 1997.

[22] I. K. Gipson, S. B. Ho, S. J. Spurr-Michaud et al., "Mucin genes expressed by human female reproductive tract epithelia," Biology of Reproduction, vol. 56, no. 4, pp. 999-1011, 1997.

[23] P. Vigil, M. E. Cortes, A. Zuniga, J. Riquelme, and F. Ceric, "Scanning electron and light microscopy study of the cervical mucus in women with polycystic ovary syndrome," Journal of Electron Microscopy, vol. 58, no. 1, pp. 21-27, 2009.

[24] L. Ming, P. Xiaoling, L. Yan et al., "Purification of antimicrobial factors from human cervical mucus," Human Reproduction, vol. 22, no. 7, pp. 1810-1815, 2007.

[25] J. Ravel, P. Gajer, Z. Abdo et al., "Vaginal microbiome of reproductive-age women," Proceedings of the National Academy of Sciences of the United States of America, vol. 108, no. 1, pp. 4680-4687, 2011.

[26] P. M. Starkey, L. M. Clover, and M. C. P. Rees, "Variation during the menstrual cycle of immune cell populations in human endometrium," European Journal of Obstetrics and Gynecology and Reproductive Biology, vol. 39, no. 3, pp. 203-207, 1991.

[27] N. Iijima, M. M. Linehan, M. Zamora et al., "Dendritic cells and B cells maximize mucosal Th1 memory response to herpes simplex virus," Journal of Experimental Medicine, vol. 205, no. 13, pp. 3041-3052, 2008.

[28] D. O. Ochiel, M. Ghosh, J. V. Fahey, P. M. Guyre, and C. R. Wira, "Human uterine epithelial cell secretions regulate dendritic cell differentiation and responses to TLR ligands," Journal of Leukocyte Biology, vol. 88, no. 3, pp. 435-444, 2010.

[29] T. F. Mselle, S. K. Meadows, M. Eriksson et al., "Unique characteristics of NK cells throughout the human female reproductive tract," Clinical Immunology, vol. 124, no. 1, pp. 69-76, 2007.

[30] S. E. Bloomfield and C. Lopez, "Herpes infections in the immunosuppressed host.," Ophthalmology, vol. 87, no. 12, pp. 1226-1235, 1980.

[31] M. E. Selsted and A. J. Ouellette, "Defensins in granules of phagocytic and non-phagocytic cells," Trends in Cell Biology, vol. 5, no. 3, pp. 114-119, 1995.

[32] G. Trinchieri, “Type I interferon: friend or foe?" Journal of Experimental Medicine, vol. 207, no. 10, pp. 2053-2063, 2010.

[33] M. Eriksson, S. K. Meadows, C. R. Wira, and C. L. Sentman, "Endogenous transforming growth factor- $\beta$ inhibits toll-like receptor mediated activation of human uterine natural killer cells," The American Journal of Reproductive Immunology, vol. 56, no. 5-6, pp. 321-328, 2006.

[34] M. J. Keller, E. Guzman, E. Hazrati et al., "PRO 2000 elicits a decline in genital tract immune mediators without compromising intrinsic antimicrobial activity," AIDS, vol. 21, no. 4, pp. 467476, 2007.

[35] L. M. Bebell, J.-A. Passmore, C. Williamson et al., "Relationship between levels of inflammatory cytokines in the genital tract and $\mathrm{CD} 4^{+}$cell counts in women with acute HIV-1 infection," The Journal of Infectious Diseases, vol. 198, no. 5, pp. 710-714, 2008.

[36] L. R. Mukura, M. Ghosh, J. V. Fahey, S. Cu-Uvin, and C. R. Wira, "Genital tract viral load in HIV type 1-positive women correlates with specific cytokine levels in cervical-vaginal secretions but is 
not a determinant of infectious virus or anti-HIV activity," AIDS Research and Human Retroviruses, vol. 28, no. 11, pp. 1533-1539, 2012.

[37] C. Mitchell, J. Hitti, K. Paul et al., "Cervicovaginal shedding of HIV type 1 is related to genital tract inflammation independent of changes in vaginal microbiota," AIDS Research and Human Retroviruses, vol. 27, no. 1, pp. 35-39, 2011.

[38] C. A. Blish, R. S. McClelland, B. A. Richardson et al., "Genital inflammation predicts HIV-1 shedding independent of plasma viral load and systemic inflammation," Journal of Acquired Immune Deficiency Syndromes, vol. 61, no. 4, pp. 436-440, 2012.

[39] T. R. Mosmann, H. Cherwinski, M. W. Bond, M. A. Giedlin, and R. L. Coffman, "Two types of murine helper T cell clone. I. Definition according to profiles of lymphokine activities and secreted proteins," Journal of Immunology, vol. 136, no. 7, pp. 2348-2357, 1986.

[40] S. Sakaguchi, "Naturally arising $\mathrm{CD}^{+}$regulatory $\mathrm{T}$ cells for immunologic self-tolerance and negative control of immune responses," Annual Review of Immunology, vol. 22, pp. 531-562, 2004.

[41] T. R. Mosmann and R. L. Coffman, “TH1 and TH2 cells: different patterns of lymphokine secretion lead to different functional properties," Annual Review of Immunology, vol. 7, pp. 145-173, 1989.

[42] H. Park, Z. Li, X. O. Yang et al., "A distinct lineage of CD4 T cells regulates tissue inflammation by producing interleukin 17," Nature Immunology, vol. 6, no. 11, pp. 1133-1141, 2005.

[43] L. E. Harrington, R. D. Hatton, P. R. Mangan et al., "Interleukin 17-producing CD4+ effector T cells develop via a lineage distinct from the T helper type 1 and 2 lineages," Nature Immunology, vol. 6, no. 11, pp. 1123-1132, 2005.

[44] J. Lieberman, “The ABCs of granule-mediated cytotoxicity: new weapons in the arsenal," Nature Reviews Immunology, vol. 3, no. 5, pp. 361-370, 2003.

[45] Y. Nakanishi, B. Lu, C. Gerard, and A. Iwasaki, "CD8 + T lymphocyte mobilization to virus-infected tissue requires CD4 + T-cell help," Nature, vol. 462, no. 7272, pp. 510-513, 2009.

[46] B. R. Kamat and P. G. Isaacson, "The immunocytochemical distribution of leukocytic subpopulations in human endometrium," The American Journal of Pathology, vol. 127, no. 1, pp. 66-73, 1987.

[47] A. L. Givan, H. D. White, J. E. Stern et al., "Flow cytometric analysis of leukocytes in the human female reproductive tract: comparison of fallopian tube, uterus, cervix, and vagina," The American Journal of Reproductive Immunology, vol. 38, no. 5, pp. 350-359, 1997.

[48] H. D. White, K. M. Crassi, A. L. Givan et al., "CD3 ${ }^{+}$CD8 ${ }^{+}$CTL activity within the human female reproductive tract: influence of stage of the menstrual cycle and menopause," The Journal of Immunology, vol. 158, no. 6, pp. 3017-3027, 1997.

[49] E. N. Kersh, T. Henning, S. A. Vishwanathan et al., "SHIV susceptibility changes during the menstrual cycle of pigtail macaques," Journal of Medical Primatology, 2014.

[50] M. Rodriguez-Garcia, M. V. Patel, and C. R. Wira, "Innate and adaptive anti-HIV immune responses in the female reproductive tract," Journal of Reproductive Immunology, vol. 97, no. 1, pp. 74-84, 2013.

[51] S. Rahman, R. Rabbani, C. Wachihi et al., "Mucosal serpin A1 and A3 levels in HIV highly exposed sero-negative women are affected by the menstrual cycle and hormonal contraceptives but are independent of epidemiological confounders," American Journal of Reproductive Immunology, vol. 69, no. 1, pp. 6472, 2013.

[52] B. L. Shacklett, "Cell-mediated immunity to HIV in the female reproductive tract," Journal of Reproductive Immunology, vol. 83, no. 1-2, pp. 190-195, 2009.

[53] J. M. Woof and J. Mestecky, "Mucosal immunoglobulins," Immunological Reviews, vol. 206, pp. 64-82, 2005.

[54] M. W. Russell and J. Mestecky, "Humoral immune responses to microbial infections in the genital tract," Microbes and Infection, vol. 4, no. 6, pp. 667-677, 2002.

[55] M. Johansson and N. Y. Lycke, "Immunology of the human genital tract," Current Opinion in Infectious Diseases, vol. 16, no. 1, pp. 43-49, 2003.

[56] K. W. Beagley and C. M. Gockel, "Regulation of innate and adaptive immunity by the female sex hormones oestradiol and progesterone," FEMS Immunology and Medical Microbiology, vol. 38, no. 1, pp. 13-22, 2003.

[57] L. A. Shrier, F. P. Bowman, M. Lin, and P. A. Crowley-Nowick, "Mucosal immunity of the adolescent female genital tract," Journal of Adolescent Health, vol. 32, no. 3, pp. 183-186, 2003.

[58] R. D. Franklin and W. H. Kutteh, "Characterization of immunoglobulins and cytokines in human cervical mucus: influence of exogenous and endogenous hormones," Journal of Reproductive Immunology, vol. 42, no. 2, pp. 93-106, 1999.

[59] W. H. Kutteh, S. J. Prince, K. R. Hammond, C. C. Kutteh, and J. Mestecky, "Variations in immunoglobulins and IgA subclasses of human uterine cervical secretions around the time of ovulation," Clinical and Experimental Immunology, vol. 104, no. 3, pp. 538-542, 1996.

[60] F. X. Lu, Z. Ma, T. Rourke, S. Srinivasan, M. Mcchesney, and C. J. Miller, "Immunoglobulin concentrations and antigen-specific antibody levels in cervicovaginal lavages of rhesus macaques are influenced by the stage of the menstrual cycle," Infection and Immunity, vol. 67, no. 12, pp. 6321-6328, 1999.

[61] M. Relloso, L. Aragoneses-Fenoll, S. Lasarte et al., "Estradiol impairs the Th17 immune response against candida albicans," Journal of Leukocyte Biology, vol. 91, no. 1, pp. 159-165, 2012.

[62] S. Lasarte, D. Elsner, M. Guia-Gonzalez et al., "Female sex hormones regulate the Th17 immune response to sperm and Candida albicans," Human Reproduction, vol. 28, no. 12, pp. 3283-3291, 2013.

[63] S. Kovats, "Estrogen receptors regulate an inflammatory pathway of dendritic cell differentiation: mechanisms and implications for immunity," Hormones and Behavior, vol. 62, no. 3, pp. 254-262, 2012.

[64] L. Brabin, "Interactions of the female hormonal environment, susceptibility to viral infections, and disease progression," AIDS Patient Care and STDs, vol. 16, no. 5, pp. 211-221, 2002.

[65] J. Mestecky, "Humoral immune responses to the human immunodeficiency virus type-1 (HIV-1) in the genital tract compared to other mucosal sites," Journal of Reproductive Immunology, vol. 73, no. 1, pp. 86-97, 2007.

[66] M. Ghosh, J. V. Fahey, Z. Shen et al., "Anti-HIV activity in cervical-vaginal secretions from HIV-positive and -negative women correlate with innate antimicrobial levels and IgG antibodies," PLoS ONE, vol. 5, no. 6, Article ID el1366, 2010.

[67] R. Y. Choi, P. Levinson, B. L. Guthrie et al., "Cervicovaginal HIV-1-neutralizing immunoglobulin A detected among HIV1-exposed seronegative female partners in HIV-1-discordant couples," AIDS, vol. 26, no. 17, pp. 2155-2163, 2012. 
[68] D. Trabattoni, M. Biasin, and M. Clerici, "Mucosal immunoglobulin A in HIV-exposed seronegative individuals," AIDS, vol. 26, no. 17, pp. 2247-2250, 2012.

[69] C. Devito, J. Hinkula, R. Kaul et al., "Mucosal and plasma IgA from HIV-exposed seronegative individuals neutralize a primary HIV-1 isolate," AIDS, vol. 14, no. 13, pp. 1917-1920, 2000.

[70] D. Tudor, M. Derrien, L. Diomede et al., "HIV-1 gp41-specific monoclonal mucosal IgAs derived from highly exposed but IgG-seronegative individuals block HIV-1 epithelial transcytosis and neutralize $\mathrm{CD}^{+}$cell infection: an $\operatorname{IgA}$ gene and functional analysis," Mucosal Immunology, vol. 2, no. 5, pp. 412426, 2009.

[71] K. E. Seaton, L. Ballweber, A. Lan et al., "HIV-1 specific IgA detected in vaginal secretions of HIV uninfected women participating in a microbicide trial in Southern Africa are primarily directed toward gp120 and gp140 specificities," PLoS ONE, vol. 9, no. 7, Article ID e101863, 2014.

[72] B. Su and C. Moog, "Which antibody functions are important for an HIV vaccine?" Frontiers in Immunology, vol. 5, article 289, 2014.

[73] T. Schiffner, Q. J. Sattentau, and L. Dorrell, "Development of prophylactic vaccines against HIV-1," Retrovirology, vol. 10, article 72, 2013.

[74] X. Wu, Z. Y. Yang, Y. Li et al., "Rational design of envelope identifies broadly neutralizing human monoclonal antibodies to HIV-1," Science, vol. 329, no. 5993, pp. 856-861, 2010.

[75] L. M. Walker, M. Huber, K. J. Doores et al., "Broad neutralization coverage of HIV by multiple highly potent antibodies," Nature, vol. 477, no. 7365, pp. 466-470, 2011.

[76] J. United, "Towards universal access: scaling up priority HIV/AIDS interventions in the health sector," Progress Report 2010, 2010.

[77] A. Nicolosi, M. L. C. Leite, M. Musicco, C. Arici, G. Gavazzeni, and A. Lazzarin, "The efficiency of male-to-female and femaleto-male sexual transmission of the human immunodeficiency virus: a study of 730 stable couples," Epidemiology, vol. 5, no. 6, pp. 570-575, 1994.

[78] C. J. Miller, Q. Li, K. Abel et al., "Propagation and dissemination of infection after vaginal transmission of simian immunodeficiency virus," Journal of Virology, vol. 79, no. 14, pp. 9217-9227, 2005.

[79] Z.-Q. Zhang, S. W. Wietgrefe, Q. Li et al., "Roles of substrate availability and infection of resting and activated $\mathrm{CD}^{+} \mathrm{T}$ cells in transmission and acute simian immunodeficiency virus infection," Proceedings of the National Academy of Sciences of the United States of America, vol. 101, no. 15, pp. 5640-5645, 2004.

[80] Q. J. Sattentau, A. G. Dalgleish, R. A. Weiss, and P. C. L. Beverley, "Epitopes of the CD4 antigen and HIV infection," Science, vol. 234, no. 4780, pp. 1120-1123, 1986.

[81] H. Deng, R. Liu, W. Ellmeier et al., "Identification of a major co-receptor for primary isolates of HIV-1," Nature, vol. 381, no. 6584, pp. 661-666, 1996.

[82] Y. Feng, C. C. Broder, P. E. Kennedy, and E. A. Berger, "HIV1 entry cofactor: functional cDNA cloning of a seven-transmembrane, G protein-coupled receptor," Science, vol. 272, no. 5263, pp. 872-877, 1996.

[83] C. Cicala, J. Arthos, and A. S. Fauci, "HIV-1 envelope, integrins and co-receptor use in mucosal transmission of HIV," Journal of Translational Medicine, vol. 9, no. 1, article S2, 2010.

[84] S. G. Turville, J. Arthos, K. MacDonald et al., "HIV gp120 receptors on human dendritic cells," Blood, vol. 98, no. 8, pp. 2482-2488, 2001.
[85] M. Patel, M. Yanagishita, G. Roderiquez et al., "Cell-surface heparan sulfate proteoglycan mediates HIV-1 infection of T-cell lines," AIDS Research and Human Retroviruses, vol. 9, no. 2, pp. 167-174, 1993.

[86] E. Stoddard, G. Cannon, H. Ni et al., "gp340 expressed on human genital epithelia binds HIV-1 envelope protein and facilitates viral transmission," The Journal of Immunology, vol. 179, no. 5, pp. 3126-3132, 2007.

[87] J. Arthos, C. Cicala, E. Martinelli et al., "HIV-1 envelope protein binds to and signals through integrin $\alpha 4 \beta 7$, the gut mucosal homing receptor for peripheral T cells," Nature Immunology, vol. 9, no. 3, pp. 301-309, 2008.

[88] S. M. Smith, M. Mefford, D. Sodora et al., “Topical estrogen protects against SIV vaginal transmission without evidence of systemic effect," AIDS, vol. 18, no. 12, pp. 1637-1643, 2004.

[89] P. A. Marx, A. I. Spira, A. Gettie et al., "Progesterone implants enhance SIV vaginal transmission and early virus load," Nature Medicine, vol. 2, no. 10, pp. 1084-1089, 1996.

[90] L. Miller, D. L. Patton, A. Meier, S. S. Thwin, T. M. Hooton, and D. A. Eschenbach, "Depomedroxyprogesterone-induced hypoestrogenism and changes in vaginal flora and epithelium," Obstetrics \& Gynecology, vol. 96, no. 2, pp. 431-439, 2000.

[91] K. Nilsson, B. Risberg, and G. Heimer, "The vaginal epithelium in the postmenopause-cytology, histology and $\mathrm{pH}$ as methods of assessment," Maturitas, vol. 21, no. 1, pp. 51-56, 1995.

[92] P. Aaby, K. Ariyoshi, M. Buckner et al., "Age of wife as a major determinant of male-to-female transmission of HIV-2 infection: a community study from rural West Africa," AIDS, vol. 10, no. 13, pp. 1585-1590, 1996.

[93] X. Tan, R. Pearce-Pratt, and D. M. Phillips, "Productive infection of a cervical epithelial cell line with human immunodeficiency virus: implications for sexual transmission," Journal of Virology, vol. 67, no. 11, pp. 6447-6452, 1993.

[94] A. L. Howell, R. D. Edkins, S. E. Rier et al., "Human immunodeficiency virus type 1 infection of cells and tissues from the upper and lower human female reproductive tract," Journal of Virology, vol. 71, no. 5, pp. 3498-3506, 1997.

[95] S. N. Asin, D. Wildt-Perinic, S. I. Mason, A. L. Howell, C. R. Wira, and M. W. Fanger, "Human immunodeficiency virus type 1 infection of human uterine epithelial cells: viral shedding and cell contact-mediated infectivity," The Journal of Infectious Diseases, vol. 187, no. 10, pp. 1522-1533, 2003.

[96] Z. Wu, Z. Chen, and D. M. Phillips, "Human genital epithelial cells capture cell-free human immunodeficiency virus type 1 and transmit the virus to $\mathrm{CD} 4^{+}$Cells: implications for mechanisms of sexual transmission," Journal of Infectious Diseases, vol. 188, no. 10, pp. 1473-1482, 2003.

[97] S. N. Asin, M. W. Fanger, D. Wildt-Perinic, P. L. Ware, C. R. Wira, and A. L. Howell, "Transmission of HIV-1 by primary human uterine epithelial cells and stromal fibroblasts," Journal of Infectious Diseases, vol. 190, no. 2, pp. 236-245, 2004.

[98] H. Saïdi, G. Magri, N. Nasreddine, M. Réquena, and L. Bélec, "R5- and X4-HIV-1 use differentially the endometrial epithelial cells HEC-1A to ensure their own spread: implication for mechanisms of sexual transmission," Virology, vol. 358, no. 1, pp. 55-68, 2007.

[99] A. M. Micsenyi, C. Zony, R. A. Alvarez, N. D. Durham, B. K. Chen, and M. E. Klotman, "Postintegration HIV-1 infection of cervical epithelial cells mediates contact-dependent productive infection of t cells," Journal of Infectious Diseases, vol. 208, no. 11, pp. 1756-1767, 2013. 
[100] J.-C. Grivel, R. J. Shattock, and L. B. Margolis, "Selective transmission of R5 HIV-1 variants: where is the gatekeeper?" Journal of Translational Medicine, vol. 9, supplement 1, article S6, 2010.

[101] M. Bomsel and V. David, "Mucosal gatekeepers: selecting HIV viruses for early infection," Nature Medicine, vol. 8, no. 2, pp. 114-116, 2002.

[102] W. W. Agace, A. Amara, A. I. Roberts et al., "Constitutive expression of stromal derived factor-1 by mucosal epithelia and its role in HIV transmission and propagation," Current Biology, vol. 10, no. 6, pp. 325-328, 2000.

[103] A. Alfsen, H. Yu, A. Magérus-Chatinet, A. Schmitt, and M. Bomsel, "HIV-1-infected blood mononuclear cells form an integrin- and agrin-dependent viral synapse to induce efficient HIV-1 transcytosis across epithelial cell monolayer," Molecular Biology of the Cell, vol. 16, no. 9, pp. 4267-4279, 2005.

[104] E. Saba, J.-C. Grivel, C. Vanpouille et al., "HIV-1 sexual transmission: early events of HIV-1 infection of human cervicovaginal tissue in an optimized ex vivo model," Mucosal Immunology, vol. 3, no. 3, pp. 280-290, 2010.

[105] A. Kohli, A. Islam, D. L. Moyes et al., "Oral and vaginal epithelial cell lines bind and transfer cell-free infectious HIV-1 to permissive cells but are not productively infected," PLOS ONE, vol. 9, no. 5, Article ID e98077, 2014.

[106] D. Maher, X. Wu, T. Schacker, J. Horbul, and P. Southern, "HIV binding, penetration, and primary infection in human cervicovaginal tissue," Proceedings of the National Academy of Sciences of the United States of America, vol. 102, no. 32, pp. 11504-11509, 2005.

[107] A. Nazli, O. Chan, W. N. Dobson-Belaire et al., "Exposure to HIV-1 directly impairs mucosal epithelial barrier integrity allowing microbial translocation," PLoS Pathogens, vol. 6, no. 4, pp. 1-20, 2010.

[108] F. Hladik and M. J. McElrath, "Setting the stage: host invasion by HIV," Nature Reviews Immunology, vol. 8, no. 6, pp. 447-457, 2008.

[109] A. T. Haase, "Early events in sexual transmission of HIV and SIV and opportunities for interventions," Annual Review of Medicine, vol. 62, pp. 127-139, 2011.

[110] F. Blanchet, A. Moris, J. P. Mitchell, and V. Piguet, "A look at HIV journey: from dendritic cells to infection spread in CD4+ T cells," Current Opinion in HIV and AIDS, vol. 6, no. 5, pp. 391397, 2011.

[111] M. Lambotin, S. Raghuraman, F. Stoll-Keller, T. F. Baumert, and $\mathrm{H}$. Barth, "A look behind closed doors: interaction of persistent viruses with dendritic cells," Nature Reviews Microbiology, vol. 8, no. 5, pp. 350-360, 2010.

[112] S. I. Gringhuis, M. van der Vlist, L. M. van den Berg, J. den Dunnen, M. Litjens, and T. B. H. Geijtenbeek, "HIV-1 exploits innate signaling by TLR8 and DC-SIGN for productive infection of dendritic cells," Nature Immunology, vol. 11, no. 5, pp. 419-426, 2010.

[113] M. Rodríguez-García, N. Climent, H. Oliva et al., "Increased $\alpha$-defensins 1-3 production by dendritic cells in HIV-infected individuals is associated with slower disease progression," PLoS ONE, vol. 5, no. 2, Article ID e9436, 2010.

[114] L. De Witte, A. Nabatov, M. Pion et al., "Langerin is a natural barrier to HIV-1 transmission by Langerhans cells," Nature Medicine, vol. 13, no. 3, pp. 367-371, 2007.

[115] L. Wu and V. N. KewalRamani, "Dendritic-cell interactions with HIV: infection and viral dissemination," Nature Reviews Immunology, vol. 6, no. 11, pp. 859-868, 2006.
[116] L. Ballweber, B. Robinson, A. Kreger et al., "Vaginal Langerhans cells nonproductively transporting HIV-1 mediate infection of T cells," Journal of Virology, vol. 85, no. 24, pp. 13443-13447, 2011.

[117] F. Hladik, P. Sakchalathorn, L. Ballweber et al., "Initial events in establishing vaginal entry and infection by human immunodeficiency virus type-1," Immunity, vol. 26, no. 2, pp. 257-270, 2007.

[118] C. L. Cavellani, L. P. Rocha, S. C. da Silva Rosa et al., "The influence of AIDS on the morphometric and immune status of the uterine cervix of autopsied patients," Current HIV Research, vol. 9, no. 8, pp. 606-612, 2011.

[119] G. Levi, J. Feldman, S. Holman et al., "Relationship between HIV viral load and Langerhans cells of the cervical epithelium," Journal of Obstetrics and Gynaecology Research, vol. 31, no. 2, pp. 178-184, 2005.

[120] A. Blauvelt, M. Clerici, D. R. Lucey et al., "Functional studies of epidermal langerhans cells and blood monocytes in HIVlnfected persons," Journal of Immunology, vol. 154, no. 7, pp. 3506-3515, 1995.

[121] J. Ennen, I. Seipp, S. G. Norley, and R. Kurth, "Decreased accessory cell function of macrophages after infection with human immunodeficiency virus type 1 in vitro," European Journal of Immunology, vol. 20, no. 11, pp. 2451-2456, 1990.

[122] H. L. Twigg III, J. C. Weissler, B. Yoffe, E. J. Ball, and M. F. Lipscomb, "Monocyte accessory cell function in patients infected with the human immunodeficiency virus," Clinical Immunology and Immunopathology, vol. 59, no. 3, pp. 436-448, 1991.

[123] B.-A. Biggs, M. Hewish, S. Kent, K. Hayes, and S. M. Crowe, "HIV-1 infection of human macrophages impairs phagocytosis and killing of Toxoplasma gondii," Journal of Immunology, vol. 154, no. 11, pp. 6132-6139, 1995.

[124] S. M. Crowe, "Role of macrophages in the pathogenesis of human immunodeficiency virus (HIV) infection," Australian and New Zealand Journal of Medicine, vol. 25, no. 6, pp. 777783, 1995.

[125] K. Kedzierska, R. Azzam, P. Ellery, J. Mak, A. Jaworowski, and S. M. Crowe, "Defective phagocytosis by human monocyte/macrophages following HIV-1 infection: underlying mechanisms and modulation by adjunctive cytokine therapy," Journal of Clinical Virology, vol. 26, no. 2, pp. 247-263, 2003.

[126] D. L. Pitrak, K. M. Mullane, M. L. Bilek, P. Stevens, and R. C. Allen, "Impaired phagocyte oxidative capacity in patients with human immunodeficiency virus infection," Journal of Laboratory and Clinical Medicine, vol. 132, no. 4, pp. 284-293, 1998.

[127] E. Olivetta, V. Tirelli, C. Chiozzini et al., "HIV-1 Nef impairs key functional activities in human macrophages through CD36 downregulation," PLoS ONE, vol. 9, no. 4, Article ID e93699, 2014.

[128] A.-S. Dugast, A. Tonelli, C. T. Berger et al., "Decreased Fc receptor expression on innate immune cells is associated with impaired antibody-mediated cellular phagocytic activity in chronically HIV-1 infected individuals," Virology, vol. 415, no. 2, pp. 160-167, 2011.

[129] D. S. Tyler, S. D. Stanley, C. A. Nastala et al., "Alterations in antibody-dependent cellular cytotoxicity during the course of HIV-1 infection: humoral and cellular defects," Journal of Immunology, vol. 144, no. 9, pp. 3375-3384, 1990.

[130] S. D. Tachado, J. Zhang, J. Zhu, N. Patel, and H. Koziel, "HIV impairs TNF- $\alpha$ release in response to toll-like receptor 
4 stimulation in human macrophages in vitro," The American Journal of Respiratory Cell and Molecular Biology, vol. 33, no. 6, pp. 610-621, 2005.

[131] D. M. Zhu, J. Shi, S. Liu, Y. Liu, and D. Zheng, "HIV infection enhances TRAIL-induced cell death in macrophage by downregulating decoy receptor expression and generation of reactive oxygen species," PLoS ONE, vol. 6, no. 4, Article ID e18291, 2011.

[132] K. B. Collins, B. K. Patterson, G. J. Naus, D. V. Landers, and P. Gupta, "Development of an in vitro organ culture model to study transmission of HIV-1 in the female genital tract," Nature Medicine, vol. 6, no. 4, pp. 475-479, 2000.

[133] P. Greenhead, P. Hayes, P. S. Watts, K. G. Laing, G. E. Griffin, and R. J. Shattock, "Parameters of human immunodeficiency virus infection of human cervical tissue and inhibition by vaginal virucides," Journal of Virology, vol. 74, no. 12, pp. 5577-5586, 2000.

[134] J. E. Cummins Jr., J. Guarner, L. Flowers et al., "Preclinical testing of candidate topical microbicides for anti-human immunodeficiency virus type 1 activity and tissue toxicity in a human cervical explant culture," Antimicrobial Agents and Chemotherapy, vol. 51, no. 5, pp. 1770-1779, 2007.

[135] N. Sharova, C. Swingler, M. Sharkey, and M. Stevenson, "Macrophages archive HIV-1 virions for dissemination in trans," The EMBO Journal, vol. 24, no. 13, pp. 2481-2489, 2005.

[136] J. Chehimi, Q. Luo, L. Azzoni et al., "HIV-1 transmission and cytokine-induced expression of DC-SIGN in human monocytederived macrophages," Journal of Leukocyte Biology, vol. 74, no. 5, pp. 757-763, 2003.

[137] R. Shen, H. E. Richter, R. H. Clements et al., "Macrophages in vaginal but not intestinal mucosa are monocyte-like and permissive to human immunodeficiency virus type 1 infection," Journal of Virology, vol. 83, no. 7, pp. 3258-3267, 2009.

[138] E. Cassol, L. Cassetta, M. Alfano, and G. Poli, "Macrophage polarization and HIV-1 infection," Journal of Leukocyte Biology, vol. 87, no. 4, pp. 599-608, 2010.

[139] M. Firoz Mian and A. A. Ashkar, "Induction of innate immune responses in the female genital tract: friend or foe of HIV-1 infection?" American Journal of Reproductive Immunology, vol. 65, no. 3, pp. 344-351, 2011.

[140] C. Rollenhagen and S. N. Asin, "Enhanced HIV-1 replication in ex vivo ectocervical tissues from post-menopausal women correlates with increased inflammatory responses," Mucosal Immunology, vol. 4, no. 6, pp. 671-681, 2011.

[141] H. Xu, X. Wang, L. A. Morici, B. Pahar, and R. S. Veazey, "Early divergent host responses in SHIVsf162p3 and SIVmac251 infected macaques correlate with control of viremia," PLoS ONE, vol. 6, no. 3, Article ID e17965, 2011.

[142] K. Abel, D. M. Rocke, B. Chohan, L. Fritts, and C. J. Miller, "Temporal and anatomic relationship between virus replication and cytokine gene expression after vaginal simian immunodeficiency virus infection," Journal of Virology, vol. 79, no. 19, pp. 12164-12172, 2005.

[143] Q. Li, J. D. Estes, P. M. Schlievert et al., "Glycerol monolaurate prevents mucosal SIV transmission," Nature, vol. 458, no. 7241, pp. 1034-1038, 2009.

[144] J. Lajoie, J. Poudrier, M. Massinga Loembe et al., "Chemokine expression patterns in the systemic and genital tract compartments are associated with HIV-1 infection in women from benin," Journal of Clinical Immunology, vol. 30, no. 1, pp. 90-98, 2010.
[145] M. Rancez, A. Couëdel-Courteille, and R. Cheynier, "Chemokines at mucosal barriers and their impact on HIV infection," Cytokine \& Growth Factor Reviews, vol. 23, no. 4-5, pp. 233-243, 2012.

[146] G. Simmons, J. D. Reeves, S. Hibbitts et al., "Co-receptor use by HIV and inhibition of HIV infection by chemokine receptor ligands,' Immunological Reviews, vol. 177, no. 1, pp. 112-126, 2000.

[147] Y. Ghiglione and G. Turk, "Nef performance in macrophages: the master orchestrator of viral persistence and spread," Current HIV Research, vol. 9, no. 7, pp. 505-513, 2011.

[148] E. Olivetta, D. Pietraforte, I. Schiavoni, M. Minetti, M. Federico, and M. Sanchez, "HIV-1 Nef regulates the release of superoxide anions from human macrophages," Biochemical Journal, vol. 390, no. 2, pp. 591-602, 2005.

[149] E. Olivetta, C. Mallozzi, V. Ruggieri, D. Pietraforte, M. Federico, and M. Sanchez, "HIV-1 Nef induces p47phox phosphorylation leading to a rapid superoxide anion release from the U937 human monoblastic cell line," Journal of Cellular Biochemistry, vol. 106, no. 5, pp. 812-822, 2009.

[150] S. Swingler, A. Mann, J.-M. Jacqué et al., "HIV-1 nef mediates lymphocyte chemotaxis and activation by infected macrophages," Nature Medicine, vol. 5, no. 9, pp. 997-1003, 1999.

[151] S. D. Briggs, B. Scholtz, J.-M. Jacque, S. Swingler, M. Stevenson, and T. E. Smithgall, "HIV-1 Nef promotes survival of myeloid cells by a Stat3-dependent pathway," The Journal of Biological Chemistry, vol. 276, no. 27, pp. 25605-25611, 2001.

[152] M. Federico, Z. Percario, E. Olivetta et al., "HIV-1 Nef activates STAT1 in human monocytes/macrophages through the release of soluble factors," Blood, vol. 98, no. 9, pp. 2752-2761, 2001.

[153] N. N. Nkwanyana, P. P. Gumbi, L. Roberts et al., "Impact of human immunodeficiency virus 1 infection and inflammation on the composition and yield of cervical mononuclear cells in the female genital tract," Immunology, vol. 128, no. 1, pp. e746e757, 2009.

[154] A. van de Vyver, E. Delport, and A. Visser, "Decreased CD10 expression in the bone marrow neutrophils of HIV positive patients," Mediterranean Journal of Hematology and Infectious Diseases, vol. 2, no. 3, Article ID e2010032, 2010.

[155] T. Cloke, M. Munder, G. Taylor, I. Müller, and P. Kropf, "Characterization of a novel population of low-density granulocytes associated with disease severity in HIV-1 infection," PLoS ONE, vol. 7, no. 11, Article ID e48939, 2012.

[156] T. Cloke, M. Munder, P. Bergin et al., "Phenotypic alteration of neutrophils in the blood of HIV seropositive patients," PLoS ONE, vol. 8, no. 9, Article ID e72034, 2013.

[157] N. L. Bowers, E. S. Helton, R. P. H. Huijbregts, P. A. Goepfert, S. L. Heath, and Z. Hel, "Immune suppression by neutrophils in HIV-1 infection: role of PD-L1/PD-1 pathway," PLoS Pathogens, vol. 10, no. 3, Article ID e1003993, 2014.

[158] A. Smalls-Mantey, M. Connors, and Q. J. Sattentau, "Comparative efficiency of HIV-1-infected T cell killing by NK cells, monocytes and neutrophils," PLoS ONE, vol. 8, no. 9, Article ID e74858, 2013.

[159] C. Speth, M. F. Brodde, M. Hagleitner et al., "Neutrophils turn plasma proteins into weapons against HIV-1," PLOS ONE, vol. 8, no. 6, Article ID e66073, 2013.

[160] S. Polzer, M. Van Yperen, M. Kirst, B. Schwalbe, H. Schaal, and M. Schreiber, "Neutralization of X4-and R5-tropic HIV-1 NL43 variants by $\mathrm{HOCl}$-modified serum albumins," BMC Research Notes, vol. 3, article 155, 2010. 
[161] J. Fu, B. E. Sha, and L. L. Thomas, "HIV-1-infected peripheral blood mononuclear cells enhance neutrophil survival and HLA-DR expression via increased production of GM-CSF: implications for HIV-1 infection," Journal of Acquired Immune Deficiency Syndromes, vol. 56, no. 1, pp. 16-25, 2011.

[162] T. Saitoh, J. Komano, Y. Saitoh et al., "Neutrophil extracellular traps mediate a host defense response to human immunodeficiency virus-1," Cell Host \& Microbe, vol. 12, no. 1, pp. 109-116, 2012.

[163] P. Levinson, R. Kaul, J. Kimani et al., "Levels of innate immune factors in genital fluids: association of alpha defensins and LL37 with genital infections and increased HIV acquisition," AIDS, vol. 23, no. 3, pp. 309-317, 2009.

[164] A. H. Rook, H. Masur, H. C. Lane et al., "Interleukin-2 enhances the depressed natural killer and cytomegalovirusspecific cytotoxic activities of lymphocytes from patients with the acquired immune deficiency syndrome," The Journal of Clinical Investigation, vol. 72, no. 1, pp. 398-403, 1983.

[165] M. M. Lederman, O. D. Ratnoff, J. J. Scillian, P. K. Jones, and B. Schacter, "Impaired cell-mediated immunity in patients with classic hemophilia," The New England Journal of Medicine, vol. 308, no. 2, pp. 79-83, 1983.

[166] M. Katzman and M. M. Lederman, "Defective postbinding lysis underlies the impaired natural killer activity in factor vii-treated, human T lymphotropic virus type III seropositive hemophiliacs," Journal of Clinical Investigation, vol. 77, no. 4, pp. 1057-1062, 1986.

[167] S. M. Dillon, E. J. Lee, J. M. Bramante, E. Barker, and C. C. Wilson, "The natural killer cell interferon-gamma response to bacteria is diminished in untreated HIV-1 infection and defects persist despite viral suppression," Journal of Acquired Immune Deficiency Syndromes, vol. 65, no. 3, pp. 259-267, 2014.

[168] A. J. Low, T. Clayton, I. Konate et al., "Genital warts and infection with human immunodeficiency virus in high-risk women in Burkina Faso: a longitudinal study," BMC Infectious Diseases, vol. 11, article 20, 2011.

[169] A. Bere, S. Tayib, J.-M. Kriek et al., "phenotype and function of NK cells infiltrating human papillomavirus (HPV)-associated genital warts during HIV infection," Clinical Immunology, vol. 150, no. 2, pp. 210-219, 2014.

[170] M. Jia, D. Li, X. He et al., "Impaired natural killer cell-induced antibody-dependent cell-mediated cytotoxicity is associated with human immunodeficiency virus-1 disease progression," Clinical and Experimental Immunology, vol. 171, no. 1, pp. 107116, 2013.

[171] S. Norris, A. Coleman, L. Kuri-Cervantes, M. Bower, M. Nelson, and M. R. Goodier, "PD-1 expression on natural killer cells and $\mathrm{CD}^{+} \mathrm{T}$ cells during chronic HIV-1 infection," Viral Immunology, vol. 25, no. 4, pp. 329-332, 2012.

[172] I. P. da Silva, A. Gallois, S. J. Baranda et al., "Reversal of NK cell exhaustion in advanced melanoma by tim-3 blockade," Cancer Immunology Research, 2014.

[173] C. Tomescu, S. Abdulhaqq, and L. J. Montaner, "Evidence for the innate immune response as a correlate of protection in human immunodeficiency virus (HIV)-1 highly exposed seronegative subjects (HESN)," Clinical and Experimental Immunology, vol. 164, no. 2, pp. 158-169, 2011.

[174] S. Boulet, M. Kleyman, J. Y. Kim et al., "A combined genotype of KIR3DL1 high expressing alleles and HLA-B $* 57$ is associated with a reduced risk of HIV infection," AIDS, vol. 22, no. 12, pp. 1487-1491, 2008.
[175] W. Jennes, S. Verheyden, C. Demanet et al., "Cutting edge: resistance to HIV-1 infection among African female sex workers is associated with inhibitory KIR in the absence of their HLA ligands," Journal of Immunology, vol. 177, no. 10, pp. 6588-6592, 2006.

[176] W. Jennes, S. Verheyden, J. W. Mertens et al., "Inhibitory KIR/HLA incompatibility between sexual partners confers protection against HIV-1 transmission," Blood, vol. 121, no. 7, pp. 1157-1164, 2013.

[177] S. Gaudieri, D. Nolan, E. McKinnon, C. S. Witt, S. Mallal, and F. T. Christiansen, "Associations between KIR epitope combinations expressed by HLA-B/-C haplotypes found in an HIV-1 infected study population may influence NK mediated immune responses," Molecular Immunology, vol. 42, no. 4, pp. 557-560, 2005.

[178] A. Iannello, O. Debbeche, S. Samarani, and A. Ahmad, "Antiviral NK cell responses in HIV infection: I. NK cell receptor genes as determinants of HIV resistance and progression to AIDS," Journal of Leukocyte Biology, vol. 84, no. 1, pp. 1-26, 2008.

[179] R. N. Koehler, G. Alter, S. Tovanabutra et al., "Natural killer cellmediated innate sieve effect on HIV-1: the impact of KIR/HLA polymorphism on HIV-1 subtype-specific acquisition in East Africa," Journal of Infectious Diseases, vol. 208, no. 8, pp. 12501254, 2013.

[180] L. R. McKinnon and R. Kaul, "Quality and quantity: mucosal CD4+T cells and HIV susceptibility," Current Opinion in HIV and AIDS, vol. 7, no. 2, pp. 195-202, 2012.

[181] Z.-Q. Zhang, T. Schuler, M. Zupancic et al., "Sexual transmission and propagation of SIV and HIV in resting and activated CD4+ T cells," Science, vol. 286, no. 5443, pp. 1353-1357, 1999.

[182] Q. Li, L. Dua, J. D. Estes et al., "Peak SIV replication in resting memory $\mathrm{CD}^{+} \mathrm{T}$ cells depletes gut lamina propria $\mathrm{CD} 4^{+} \mathrm{T}$ cells," Nature, vol. 434, no. 7037, pp. 1148-1152, 2005.

[183] M. Clerici, N. I. Stocks, R. A. Zajac et al., "Detection of three distinct patterns of $\mathrm{T}$ helper cell dysfunction in asymptomatic, human immunodeficiency virus-seropositive patients. Independence of $\mathrm{CD}^{+}$cell numbers and clinical staging," The Journal of Clinical Investigation, vol. 84, no. 6, pp. 1892-1899, 1989.

[184] S. F. Sieg, D. A. Bazdar, C. V. Harding, and M. M. Lederman, "Differential expression of interleukin-2 and gamma interferon in human immunodeficiency virus disease," Journal of Virology, vol. 75, no. 20, pp. 9983-9985, 2001.

[185] S. F. Sieg, C. V. Harding, and M. M. Lederman, "HIV-1 infection impairs cell cycle progression of $\mathrm{CD} 4^{+} \mathrm{T}$ cells without affecting early activation responses," The Journal of Clinical Investigation, vol. 108, no. 5, pp. 757-764, 2001.

[186] S. F. Sieg, J. B. Mitchem, D. A. Bazdar, and M. M. Lederman, "Close link between $\mathrm{CD}^{+}$and $\mathrm{CD}^{+} \mathrm{T}$ cell proliferation defects in patients with human immunodeficiency virus disease and relationship to extended periods of $\mathrm{CD} 4^{+}$lymphopenia," Journal of Infectious Diseases, vol. 185, no. 10, pp. 1401-1408, 2002.

[187] H. Masur, F. P. Ognibene, R. Yarchoan et al., "CD4 counts as predictors of opportunistic pneumonias in human immunodeficiency virus (HIV) infection," Annals of Internal Medicine, vol. 111, no. 3, pp. 223-231, 1989.

[188] C. Cicala, E. Martinelli, J. P. McNally et al., "The integrin $\alpha 4 \beta 7$ forms a complex with cell-surface CD4 and defines a T-cell subset that is highly susceptible to infection by HIV-1," Proceedings of the National Academy of Sciences of the United States of America, vol. 106, no. 49, pp. 20877-20882, 2009. 
[189] L. Margolis and R. Shattock, "Selective transmission of CCR5utilizing HIV-1: the "gatekeeper" problem resolved?" Nature Reviews Microbiology, vol. 4, no. 4, pp. 312-317, 2006.

[190] B. F. Keele, E. E. Giorgi, J. F. Salazar-Gonzalez et al., "Identification and characterization of transmitted and early founder virus envelopes in primary HIV-1 infection," Proceedings of the National Academy of Sciences of the United States of America, vol. 105, no. 21, pp. 7552-7557, 2008.

[191] J. F. Salazar-Gonzalez, M. G. Salazar, B. F. Keele et al., "Genetic identity, biological phenotype, and evolutionary pathways of transmitted/founder viruses in acute and early HIV-1 infection," The Journal of Experimental Medicine, vol. 206, no. 6, pp. 12731289, 2009.

[192] L. R. McKinnon, B. Nyanga, D. Chege et al., "Characterization of a human cervical CD4+ T cell subset coexpressing multiple markers of HIV susceptibility," Journal of Immunology, vol. 187, no. 11, pp. 6032-6042, 2011.

[193] A. L. Meditz, K. L. Moreau, S. MaWhinney et al., "CCR5 Expression is elevated on endocervical $\mathrm{CD}^{+}{ }^{+} \mathrm{T}$ cells in healthy postmenopausal women," Journal of Acquired Immune Deficiency Syndromes, vol. 59, no. 3, pp. 221-228, 2012.

[194] T. F. W. Wolfs, G. Zwart, M. Bakker, and J. Goudsmit, "HIV1 genomic RNA diversification following sexual and parenteral virus transmission," Virology, vol. 189, no. 1, pp. 103-110, 1992.

[195] S. M. Wolinsky, C. M. Wike, B. T. M. Korber et al., "Selective transmission of human immunodeficiency virus type-1 variants from mothers to infants," Science, vol. 255, no. 5048, pp. 11341137, 1992.

[196] T. Zhu, H. Mo, N. Wang et al., "Genotypic and phenotypic characterization of HIV-1 in patients with primary infection," Science, vol. 261, no. 5125, pp. 1179-1181, 1993.

[197] D. I. Boeras, P. T. Hraber, M. Hurlston et al., "Role of donor genital tract HIV-1 diversity in the transmission bottleneck," Proceedings of the National Academy of Sciences of the United States of America, vol. 108, no. 46, pp. E1156-E1163, 2011.

[198] J. F. Salazar-Gonzalez, E. Bailes, K. T. Pham et al., "Deciphering human immunodeficiency virus type 1 transmission and early envelope diversification by single-genome amplification and sequencing," Journal of Virology, vol. 82, no. 8, pp. 3952-3970, 2008.

[199] C. Ochsenbauer, T. G. Edmonds, H. Ding et al., "Generation of transmitted/founder HIV-1 infectious molecular clones and characterization of their replication capacity in CD4 T lymphocytes and monocyte-derived macrophages," Journal of Virology, vol. 86, no. 5, pp. 2715-2728, 2012.

[200] Z. F. Parker, S. S. Iyer, C. B. Wilen et al., “Transmitted/founder and chronic HIV-1 envelope proteins are distinguished by differential utilization of CCR5," Journal of Virology, vol. 87, no. 5, pp. 2401-2411, 2013.

[201] N. F. Parrish, F. Gao, H. Li et al., "Phenotypic properties of transmitted founder HIV-1," Proceedings of the National Academy of Sciences of the United States of America, vol. 110, no. 17, pp. 6626-6633, 2013.

[202] D. F. L. King, A. A. Siddiqui, V. Buffa et al., "Mucosal tissue tropism and dissemination of HIV-1 subtype B acute envelopeexpressing chimeric virus," Journal of Virology, vol. 87, no. 2, pp. 890-899, 2013.

[203] A. E. Hed, A. Khaitan, L. Kozhaya et al., "Susceptibility of human Th17 cells to human immunodeficiency virus and their perturbation during infection," Journal of Infectious Diseases, vol. 201, no. 6, pp. 843-854, 2010.
[204] Y. Y. Feng, A. Merchant, C. M. Kovacs, M. Loutfy, D. Persad, and M. A. Ostrowski, "Virus-specific interleukin-17-producing CD4+ T cells are detectable in early human immunodeficiency virus type 1 infection," Journal of Virology, vol. 82, no. 13, pp. 6767-6771, 2008.

[205] D. Chege, P. M. Sheth, T. Kain et al., "Sigmoid Th17 populations, the HIV latent reservoir, and microbial translocation in men on long-term antiretroviral therapy," AIDS, vol. 25, no. 6, pp. 741749, 2011.

[206] L. C. Ndhlovu, J. M. Chapman, A. R. Jha et al., "Suppression of HIV-1 plasma viral load below detection preserves IL-17 producing T cells in HIV-1 infection," AIDS, vol. 22, no. 8, pp. 990-992, 2008.

[207] C. J. Kim, A. Nazli, O. L. Rojas et al., "A role for mucosal IL-22 production and Th22 cells in HIV-associated mucosal immunopathogenesis," Mucosal Immunology, vol. 5, no. 6, pp. 670-680, 2012.

[208] K. Talbert-Slagle, K. E. Atkins, K.-K. Yan et al., "Cellular superspreaders: an epidemiological perspective on HIV infection inside the body," PLoS Pathogens, vol. 10, no. 5, Article ID e1004092, 2014.

[209] R. E. Haaland, P. A. Hawkins, J. Salazar-Gonzalez et al., "Inflammatory genital infections mitigate a severe genetic bottleneck in heterosexual transmission of subtype A and C HIV-1," PLoS Pathogens, vol. 5, no. 1, Article ID e1000274, 2009.

[210] M.-R. Abrahams, J. A. Anderson, E. E. Giorgi et al., "Quantitating the multiplicity of infection with human immunodeficiency virus type 1 subtype $C$ reveals a non-poisson distribution of transmitted variants," Journal of Virology, vol. 83, no. 13, pp. 3556-3567, 2009.

[211] J. O. Lloyd-Smith, S. J. Schreiber, P. E. Kopp, and W. M. Getz, "Superspreading and the effect of individual variation on disease emergence," Nature, vol. 438, no. 7066, pp. 355-359, 2005.

[212] M. R. Reynolds, E. Rakasz, P. J. Skinner et al., "CD8+ Tlymphocyte response to major immunodominant epitopes after vaginal exposure to simian immunodeficiency virus: too late and too little," Journal of Virology, vol. 79, no. 14, pp. 9228-9235, 2005.

[213] P. P. Gumbi, N. N. Nkwanyana, A. Bere et al., "Impact of mucosal inflammation on cervical human immunodeficiency virus (HIV-1)-specific CD8 T-cell responses in the female genital tract during chronic HIV infection," Journal of Virology, vol. 82, no. 17, pp. 8529-8536, 2008.

[214] R. Kaul, F. A. Plummer, J. Kimani et al., "HIV-1-specific mucosal $\mathrm{CD}^{8+}$ lymphocyte responses in the cervix of HIV-1-resistant prostitutes in Nairobi," Journal of Immunology, vol. 164, no. 3, pp. 1602-1611, 2000.

[215] L. Musey, J. Hughes, T. Schacker, T. Shea, L. Corey, and M. Juliana Mcelrath, "Cytotoxic-T-cell responses, viral load, and disease progression in early human immunodeficiency virus type 1 infection," The New England Journal of Medicine, vol. 337, no. 18, pp. 1267-1274, 1997.

[216] A. Bere, L. Denny, P. Naicker, W. A. Burgers, and J.-A. S. Passmore, "HIV-specific T-cell responses detected in the genital tract of chronically HIV-infected women are largely monofunctional," Immunology, vol. 139, no. 3, pp. 342-351, 2013.

[217] D. N. Fredricks, T. L. Fiedler, and J. M. Marrazzo, "Molecular identification of bacteria associated with bacterial vaginosis," The New England Journal of Medicine, vol. 353, no. 18, pp. 18991911, 2005. 
[218] R. B. Ness, K. E. Kip, S. L. Hillier et al., "A cluster analysis of bacterial vaginosis-associated microflora and pelvic inflammatory disease," The American Journal of Epidemiology, vol. 162, no. 6, pp. 585-590, 2005.

[219] R. L. Sweet, "Gynecologic conditions and bacterial vaginosis: implications for the non-pregnant patient," Infectious Diseases in Obstetrics and Gynecology, vol. 8, no. 3-4, pp. 184-190, 2000.

[220] S. E. Cohn and R. A. Clark, "Sexually transmitted diseases, HIV, and AIDS in women," Medical Clinics of North America, vol. 87, no. 5, pp. 971-995, 2003.

[221] J. M. Marrazzo, "Interpreting the epidemiology and natural history of bacterial vaginosis: are we still confused?" Anaerobe, vol. 17, no. 4, pp. 186-190, 2011.

[222] S. L. Hillier, "Diagnostic microbiology of bacterial vaginosis," American Journal of Obstetrics \& Gynecology, vol. 169, no. 2, part 2, pp. 455-459, 1993.

[223] S. J. Klebanoff and R. W. Coombs, "Viricidal effect of Lactobacillus acidophilus on human immunodeficiency virus type 1: possible role in heterosexual transmission," Journal of Experimental Medicine, vol. 174, no. 1, pp. 289-292, 1991.

[224] J. A. Hill and D. J. Anderson, "Human vaginal leukocytes and the effects of vaginal fluid on lymphocyte and macrophage defense functions," American Journal of Obstetrics and Gynecology, vol. 166, no. 2, pp. 720-726, 1992.

[225] R. Kaul, C. Pettengell, P. M. Sheth et al., "The genital tract immune milieu: an important determinant of HIV susceptibility and secondary transmission," Journal of Reproductive Immunology, vol. 77, no. 1, pp. 32-40, 2008.

[226] J. S. Coleman, J. Hitti, E. A. Bukusi et al., "Infectious correlates of HIV-1 shedding in the female upper and lower genital tracts," AIDS, vol. 21, no. 6, pp. 755-759, 2007.

[227] S. Cu-Uvin, J. W. Hogan, A. M. Caliendo, J. Harwell, K. H. Mayer, and C. C. J. Carpenter, "Association between bacterial vaginosis and expression of human immunodeficiency virus type 1 RNA in the female genital tract," Clinical Infectious Diseases, vol. 33, no. 6, pp. 894-896, 2001.

[228] B. E. Sha, M. R. Zariffard, Q. J. Wang et al., "Female genital-tract HIV load correlates inversely with Lactobacillus species but positively with bacterial vaginosis and Mycoplasma hominis," The Journal of Infectious Diseases, vol. 191, no. 1, pp. 25-32, 2005.

[229] H. L. Martin Jr., B. A. Richardson, P. M. Nyange et al., "Vaginal lactobacilli, microbial flora, and risk of human immunodeficiency virus type 1 and sexually transmitted disease acquisition," Journal of Infectious Diseases, vol. 180, no. 6, pp. 1863-1868, 1999.

[230] N. Pavic, "Is there a local production of nitrosamines by the vaginal microflora in anaerobic vaginosis/trichomoniasis?" Medical Hypotheses, vol. 15, no. 4, pp. 433-436, 1984.

[231] A. F. Nicol, A. T. G. Fernandes, and M. D. G. Bonecini-Almeida, "Immune response in cervical dysplasia induced by human papillomavirus: the influence of human immunodeficiency virus-1 co-infection-review," Memorias do Instituto Oswaldo Cruz, vol. 100, no. 1, pp. 1-12, 2005.

[232] D. Olczak-Kowalczyk, M. Daszkiewicz, B. DembowskaBagińska et al., "Bacteria and Candida yeasts in inflammations of the oral mucosa in children with secondary immunodeficiency," Journal of Oral Pathology and Medicine, vol. 41, no. 7, pp. 568-576, 2012.

[233] J. D. Sobel, "Vulvovaginal candidosis," The Lancet, vol. 369, no. 9577, pp. 1961-1971, 2007.

[234] P. Schuman, J. D. Sobel, S. E. Ohmit et al., "Mucosal candidal colonization and candidiasis in women with or at risk for human immunodeficiency virus infection. HIV Epidemiology Research Study (HERS) Group," Clinical Infectious Diseases, vol. 27, no. 5, pp. 1161-1167, 1998.

[235] A. Aggrey, F. Plummer, and I. Wamola, "Aids 1990, a year in review. Proceedings from the 6th international conference on AIDS," AIDS, vol. 4, supplement 1, pp. S1-S285, 1990.

[236] J. L. Rhoads, D. C. Wright, R. R. Redfield, and D. S. Burke, "Chronic vaginal candidiasis in women with human immunodeficiency virus infection," The Journal of the American Medical Association, vol. 257, no. 22, pp. 3105-3107, 1987.

[237] A. Ray, S. Ray, A. T. George, and N. Swaminathan, "Interventions for prevention and treatment of vulvovaginal candidiasis in women with HIV infection," Cochrane Database of Systematic Reviews, no. 8, Article ID CD008739, 2011.

[238] T. E. Taha, D. R. Hoover, G. A. Dallabetta et al., "Bacterial vaginosis and disturbances of vaginal flora: association with increased acquisition of HIV," AIDS, vol. 12, no. 13, pp. 16991706, 1998.

[239] N. Sewankambo, R. H. Gray, M. J. Wawer et al., "HIV-1 infection associated with abnormal vaginal flora morphology and bacterial vaginosis," The Lancet, vol. 350, no. 9077, pp. 546550, 1997.

[240] P. M. Oliveira, R. E. Mascarenhas, C. Lacroix et al., "Candida species isolated from the vaginal mucosa of HIV-infected women in Salvador, Bahia, Brazil," Brazilian Journal of Infectious Diseases, vol. 15, no. 3, pp. 239-244, 2011.

[241] A. Duerr, C. M. Heilig, S. F. Meikle et al., "Incident and persistent vulvovaginal candidiasis among human immunodeficiency virus-infected women: risk factors and severity," Obstetrics and Gynecology, vol. 101, no. 3, pp. 548-556, 2003.

[242] A. Helfgott, N. Eriksen, C. M. Bundrick, R. Lorimor, and B. van Eckhout, "Vaginal infections in human immunodeficiency virus-infected women," The American Journal of Obstetrics and Gynecology, vol. 183, no. 2, pp. 347-355, 2000.

[243] F. Sorvillo, A. Kovacs, P. Kerndt, A. Stek, L. Muderspach, and L. Sanchez-Keeland, "Risk factors for trichomoniasis among women with human immunodeficiency virus (HIV) infection at a public clinic in Los Angeles County, California: implications for HIV prevention," The American Journal of Tropical Medicine and Hygiene, vol. 58, no. 4, pp. 495-500, 1998.

[244] T. Apalata, W. H. Carr, W. A. Sturm, B. Longo-Mbenza, and P. Moodley, "Determinants of symptomatic vulvovaginal candidiasis among human immunodeficiency virus type 1 infected women in rural Kwazulu-natal, South Africa," Infectious Diseases in Obstetrics and Gynecology, vol. 2014, Article ID 387070, 10 pages, 2014.

[245] A. Duerr, M. F. Sierra, J. Feldman, L. M. Clarke, I. Ehrlich, and J. Dehovitz, "Immune compromise and prevalence of Candida vulvovaginitis in human immunodeficiency virus-infected women," Obstetrics \& Gynecology, vol. 90, no. 2, pp. 252-256, 1997.

[246] C. R. Cohen, A. Duerr, N. Pruithithada et al., "Bacterial vaginosis and HIV seroprevalence among female commercial sex workers in Chiang Mai, Thailand," AIDS, vol. 9, no. 9, pp. 1093-1097, 1995.

[247] M. Laga, A. Manoka, M. Kivuvu et al., "Non-ulcerative sexually transmitted diseases as risk factors for HIV-1 transmission in women: results from a cohort study," AIDS, vol. 7, no. 1, pp. 95$102,1993$.

[248] P. Losikoff, R. Fichorova, B. Snyder et al., "Genital tract interleukin- 8 but not interleukin- $1 \beta$ or interleukin- 6 concentration is associated with bacterial vaginosis and its clearance in 
HIV-infected and HIV-uninfected women," Infectious Diseases in Obstetrics and Gynecology, vol. 2007, Article ID 92307, 6 pages, 2007.

[249] A. Knežević, S. Stepanović, M. Ćupić, D. Jevtović, J. Ranin, and T. Jovanović, "Reduced quantity and hydrogen-peroxide production of vaginal lactobacilli in HIV positive women," Biomedicine and Pharmacotherapy, vol. 59, no. 9, pp. 521-523, 2005.

[250] A. Gardner, "Diagnosing fungal infections in neutropenic patients," Clinical Journal of Oncology Nursing, vol. 11, no. 1, pp. 29-32, 2007.

[251] A. Spinillo, G. Michelone, C. Cavanna, L. Colonna, E. Capuzzo, and S. Nicola, "Clinical and microbiological characteristics of symptomatic vulvovaginal candidiasis in HIV-seropositive women," Genitourinary Medicine, vol. 70, no. 4, pp. 268-272, 1994.

[252] S. Cu-Uvin, H. Ko, D. J. Jamieson et al., "Prevalence, incidence, and persistence or recurrence of trichomoniasis among human immunodeficiency virus (HIV)-positive women and among HIV-negative women at high risk for HIV infection," Clinical Infectious Diseases, vol. 34, no. 10, pp. 1406-1411, 2002.

[253] P. Kissinger, W. E. Secor, J. S. Leichliter et al., "Early repeated infections with Trichomonas vaginalis among HIV-positive and HIV-negative women," Clinical Infectious Diseases, vol. 46, no. 7, pp. 994-999, 2008.

[254] H. L. Johnson, K. G. Ghanem, J. M. Zenilman, and E. J. Erbelding, "Sexually transmitted infections and adverse pregnancy outcomes among women attending inner city public sexually transmitted diseases clinics," Sexually Transmitted Diseases, vol. 38, no. 3, pp. 167-171, 2011.

[255] R. Hou, C. Xu, S. Zhang, M. Wu, and W. Zhang, "Distribution of human papillomavirus genotype and cervical neoplasia among women with abnormal cytology in Beijing, China," International Journal of Gynecology and Obstetrics, vol. 119, no. 3, pp. 257-261, 2012.

[256] D. T. Fleming and J. N. Wasserheit, "From epidemiological synergy to public health policy and practice: The contribution of other sexually transmitted diseases to sexual transmission of HIV infection," Sexually Transmitted Infections, vol. 75, no. 1, pp. 3-17, 1999.

[257] B. Van Der Pol, C. Kwok, B. Pierre-Louis et al., "Trichomonas vaginalis infection and human immunodeficiency virus acquisition in African women," Journal of Infectious Diseases, vol. 197, no. 4, pp. 548-554, 2008.

[258] S. I. Nwadioha, I. A. Bako, I. Onwuezobe, and D. Z. Egah, "Vaginal trichomoniasis among HIV patients attending primary health care centers of Jos, Nigeria," Asian Pacific Journal of Tropical Disease, vol. 2, no. 5, pp. 337-341, 2012.

[259] R. S. McClelland, L. Lavreys, C. Katingima et al., "Contribution of HIV-1 infection to acquisition of sexually transmitted disease: a 10-year prospective study," Journal of Infectious Diseases, vol. 191, no. 3, pp. 333-338, 2005.

[260] D. H. Watts, G. Springer, H. Minkoff et al., "The occurrence of vaginal infections among HIV-infected and high-risk HIVuninfected women: longitudinal findings of the women's interagency HIV study," Journal of Acquired Immune Deficiency Syndromes, vol. 43, no. 2, pp. 161-168, 2006.

[261] K. J. Looker, G. P. Garnett, and G. P. Schmid, "An estimate of the global prevalence and incidence of herpes simplex virus type 2 infection," Bulletin of the World Health Organization, vol. 86, no. 10, pp. 805-812, 2008.
[262] H. L. Minkoff, D. Eisenberger-Matityahu, J. Feldman, R. Burk, and L. Clarke, "Prevalence and incidence of gynecologic disorders among women infected with human immunodeficiency virus," American Journal of Obstetrics and Gynecology, vol. 180, no. 4, pp. 824-836, 1999.

[263] S. J. Bersoff-Matcha, M. M. Horgan, V. J. Fraser, L. M. Mundy, and B. P. Stoner, "Sexually transmitted disease acquisition among women infected with human immunodeficiency virus type 1," Journal of Infectious Diseases, vol. 178, no. 4, pp. 11741177, 1998.

[264] F. Xu, M. R. Sternberg, B. J. Kottiri et al., “Trends in herpes simplex virus type 1 and type 2 seroprevalence in the United States," The Journal of the American Medical Association, vol. 296, no. 8, pp. 964-973, 2006.

[265] N. Nagot, A. Ouedraogo, M.-C. Defer, R. Vallo, P. Mayaud, and P. van De Perre, "Association between bacterial vaginosis and Herpes simplex virus type-2 infection: implications for HIV acquisition studies," Sexually Transmitted Infections, vol. 83, no. 5, pp. 365-368, 2007.

[266] L. Andréoletti, E. Piednoir, J. Legoff et al., "High seroprevalence of herpes simplex virus type 2 infection in French human immunodeficiency virus type 1-infected outpatients," Journal of Clinical Microbiology, vol. 43, no. 8, pp. 4215-4217, 2005.

[267] D. B. Russell, S. N. Tabrizi, J. M. Russell, and S. M. Garland, "Seroprevalence of herpes simplex virus types 1 and 2 in HIVInfected and uninfected homosexual men in a primary care setting," Journal of Clinical Virology, vol. 22, no. 3, pp. 305-313, 2001.

[268] G. Perez, J. H. Skurnick, T. N. Denny et al., "Herpes simplex type II and Mycoplasma genitalium as risk factors for heterosexual HIV transmission: report from the heterosexual HIV transmission study," International Journal of Infectious Diseases, vol. 3, no. 1, pp. 5-11, 1998.

[269] E. E. Freeman, H. A. Weiss, J. R. Glynn, P. L. Cross, J. A. Whitworth, and R. J. Hayes, "Herpes simplex virus 2 infection increases HIV acquisition in men and women: Systematic review and meta-analysis of longitudinal studies," AIDS, vol. 20, no. 1, pp. 73-83, 2006.

[270] P. van de Perre, M. Segondy, V. Foulongne et al., "Herpes simplex virus and HIV-1: deciphering viral synergy," The Lancet Infectious Diseases, vol. 8, no. 8, pp. 490-497, 2008.

[271] T. L. Cherpes, L. A. Meyn, M. A. Krohn, J. G. Lurie, and S. L. Hillier, "Association between acquisition of herpes simplex virus type 2 in women and bacterial vaginosis," Clinical Infectious Diseases, vol. 37, no. 3, pp. 319-325, 2003.

[272] L. S. Kucera, E. Leake, N. Iyer, D. Raben, and Q. N. Myrvik, "Human immunodeficiency virus type 1 (HIV-1) and herpes simplex virus type 2 (HSV-2) can coinfect and simultaneously replicate in the same human $\mathrm{CD}_{4}^{+}$cell: effect of coinfection on infectious HSV-2 and HIV-1 replication," AIDS Research and Human Retroviruses, vol. 6, no. 5, pp. 641-647, 1990.

[273] N. Ameli, P. Bacchetti, R. A. Morrow et al., "Herpes simplex virus infection in women in the WIHS: epidemiology and effect of antiretroviral therapy on clinical manifestations," AIDS, vol. 20, no. 7, pp. 1051-1058, 2006.

[274] C. M. Posavad, A. Wald, S. Kuntz et al., "Frequent reactivation of herpes simplex virus among HIV-1-infected patients treated with highly active antiretroviral therapy," The Journal of Infectious Diseases, vol. 190, no. 4, pp. 693-696, 2004.

[275] D. B. Pereira, M. H. Antoni, A. Danielson et al., "Stress as a predictor of symptomatic genetical herpes virus recurrence 
in women with human immunodeficiency virus," Journal of Psychosomatic Research, vol. 54, no. 3, pp. 237-244, 2003.

[276] C. E. French, G. Hughes, A. Nicholson et al., "Estimation of the rate of pelvic inflammatory disease diagnoses: trends in England, 2000-2008," Sexually Transmitted Diseases, vol. 38, no. 3, pp. 158-162, 2011.

[277] C. A. S. Marques, M. L. B. Menezes, and I. M. G. Coelho, "Infecção genital por Chlamydia trachomatis em casais atendidos em ambulatório de esterilidade conjugal," DST Jornal Brasileiro de Doenças, 2007.

[278] M. C. Salfa, M. A. Latino, V. Regine et al., "Prevalence and determinants of Chlamydia trachomatis infection among sexually active women in Turin, Italy," Italian Journal of Public Health, vol. 8, no. 3, pp. 295-301, 2011.

[279] M. Hvid, A. Baczynska, B. Deleuran et al., "Interleukin-1 is the initiator of Fallopian tube destruction during Chlamydia trachomatis infection," Cellular Microbiology, vol. 9, no. 12, pp. 2795-2803, 2007.

[280] C. Erridge, A. Pridmore, A. Eley, J. Stewart, and I. R. Poxton, "Lipopolysaccharides of Bacteroides fragilis, Chlamydia trachomatis and Pseudomonas aeruginosa signal via Toll-like receptor 2," Journal of Medical Microbiology, vol. 53, no. 8, pp. 735-740, 2004.

[281] Y. Bulut, E. Faure, L. Thomas et al., "Chlamydial heat shock protein 60 activates macrophages and endothelial cells through toll-like receptor 4 and MD2 in a MyD88-dependent pathway," The Journal of Immunology, vol. 168, no. 3, pp. 1435-1440, 2002.

[282] P. Ahmad-Nejad, H. Hacker, M. Rutz, S. Bauer, R. M. Vabulas, and H. Wagner, "Bacterial CpG-DNA and lipopolysaccharides activate toll-like receptors at distinct cellular compartments," European Journal of Immunology, vol. 32, no. 7, pp. 1958-1968, 2002.

[283] J. Saklatvala, "The p38 MAP kinase pathway as a therapeutic target in inflammatory disease," Current Opinion in Pharmacology, vol. 4, no. 4, pp. 372-377, 2004.

[284] K. H. Mayer and K. K. Venkatesh, "Interactions of HIV, other sexually transmitted diseases, and genital tract inflammation facilitating local pathogen transmission and acquisition," The American Journal of Reproductive Immunology, vol. 65, no. 3, pp. 308-316, 2011.

[285] A. X. Garcês, A. M. B. D. Martinez, C. V. Gonçalves, F. N. Germano, M. F. M. Barral, and V. C. Vieira, "Prevalence of Chlamydia trachomatis and risk factors associated with infection detected in endocervical sample," Revista Brasileira de Ginecologia e Obstetricia, vol. 35, no. 8, pp. 379-383, 2013.

[286] S. Cu-Uvin, A. K. DeLong, K. K. Venkatesh et al., "Genital tract HIV-1 RNA shedding among women with below detectable plasma viral load," AIDS, vol. 24, no. 16, pp. 2489-2497, 2010.

[287] S. M. Graham, L. Masese, R. Gitau et al., "Antiretroviral adherence and development of drug resistance are the strongest predictors of genital HIV-1 shedding among women initiating treatment," Journal of Infectious Diseases, vol. 202, no. 10, pp. 1538-1542, 2010.

[288] M. S. Cohen, Y. Q. Chen, M. McCauley et al., "Prevention of HIV-1 infection with early antiretroviral therapy," The New England Journal of Medicine, vol. 365, no. 6, pp. 493-505, 2011.

[289] D. Donnell, J. M. Baeten, J. Kiarie et al., "Heterosexual HIV-1 transmission after initiation of antiretroviral therapy: a prospective cohort analysis," The Lancet, vol. 375, no. 9731, pp. 20922098, 2010.

[290] D. Mabey, "Epidemiology of sexually transmitted infections: worldwide," Medicine, vol. 42, no. 6, pp. 287-290, 2014.
[291] K. Mlisana, N. Naicker, L. Werner et al., "Symptomatic vaginal discharge is a poor predictor of sexually transmitted infections and genital tract inflammation in high-risk women in South Africa," The Journal of Infectious Diseases, vol. 206, no. 1, pp. 614, 2012.

[292] J. Ding, A. Rapista, N. Teleshova et al., "Neisseria gonorrhoeae enhances HIV-1 infection of primary resting CD4+ T cells through TLR2 activation," Journal of Immunology, vol. 184, no. 6, pp. 2814-2824, 2010.

[293] J. Zhang, G. Li, A. Bafica et al., "Neisseria gonorrhoeae enhances infection of dendritic cells by HIV type 1," Journal of Immunology, vol. 174, no. 12, pp. 7995-8002, 2005.

[294] C. F. Houlihan, N. L. Larke, D. Watson-Jones et al., "Human papillomavirus infection and increased risk of HIV acquisition. A systematic review and meta-analysis," AIDS, vol. 26, no. 17 , pp. 2211-2222, 2012.

[295] E. L. Franco and D. M. Harper, "Vaccination against human papillomavirus infection: a new paradigm in cervical cancer control," Vaccine, vol. 23, no. 17-18, pp. 2388-2394, 2005.

[296] J. M. Walboomers, M. V. Jacobs, M. M. Manos et al., "Human papillomavirus is a necessary cause of invasive cervical cancer worldwide," Journal of Pathology, vol. 189, no. 1, pp. 12-19, 1999.

[297] K. Holmes, P. Sparling, W. Stamm et al., Sexually Transmitted Diseases, McGraw-Hill, 4th edition, 2007.

[298] A. R. Giuliano, G. Tortolero-Luna, E. Ferrer et al., "Epidemiology of human papillomavirus infection in men, cancers other than cervical and benign conditions," Vaccine, vol. 26, supplement 10, pp. K17-K28, 2008.

[299] M. Corti, M. F. Villafañe, E. Marona, and D. Lewi, "Anal squamous carcinoma: a new AIDS-defining cancer? Case report and literature review," Revista do Instituto de Medicina Tropical de Sao Paulo, vol. 54, no. 6, pp. 345-348, 2012.

[300] S. Seresini, M. Origoni, L. Caputo et al., " $\mathrm{CD} 4^{+} \mathrm{T}$ cells against human papillomavirus-18 E7 in patients with high-grade cervical lesions associate with the absence of the virus in the cervix," Immunology, vol. 131, no. 1, pp. 89-98, 2010.

[301] C. M. Hebner and L. A. Laimins, "Human papillomaviruses: basic mechanisms of pathogenesis and oncogenicity," Reviews in Medical Virology, vol. 16, no. 2, pp. 83-97, 2006.

[302] P. Pundhir, Y. M. Mala, R. Tripathi, B. C. Das, and S. Bhambani, "Human papillomavirus (HPV) infection and abnormal cervical cytopathology among human immuno-deficiency virus (HIV) positive women in Northern India," Journal of AIDS and HIV Research, vol. 6, no. 1, pp. 1-6, 2014.

[303] F. Mantovani and L. Banks, "The human papillomavirus E6 protein and its contribution to malignant progression," Oncogene, vol. 20, no. 54, pp. 7874-7887, 2001.

[304] M. E. McLaughlin-Drubin and K. Münger, "The human papillomavirus E7 oncoprotein," Virology, vol. 384, no. 2, pp. 335-344, 2009.

[305] R. P. Souza, F. Gimenes, A. L. P. de Abreu et al., "Differences in the mutation of the $\mathrm{p} 53$ gene in exons 6 and 7 in cervical samples from HIV- and HPV-infected women," Infectious Agents and Cancer, vol. 8, article 38, no. 1, 2013.

[306] C. Lee and L. Laimins, "The differentiation-dependent life cycle of human papillomaviruses in keratinocytes," in The Papillomaviruses, R. Garcea and D. DiMaio, Eds., pp. 45-67, Springer, New York, NY, USA, 2007.

[307] R. P. Viscidi, B. Snyder, S. Cu-Uvin et al., "Human papillomavirus capsid antibody response to natural infection and risk of subsequent HPV infection in HIV-positive and HIV-negative 
women," Cancer Epidemiology Biomarkers and Prevention, vol. 14, no. 1, pp. 283-288, 2005.

[308] N. W. J. Bulkmans, J. Berkhof, S. Bulk et al., "High-risk HPV type-specific clearance rates in cervical screening," British Journal of Cancer, vol. 96, no. 9, pp. 1419-1424, 2007.

[309] J. E. Koshiol, J. C. Schroeder, D. J. Jamieson et al., "Time to clearance of human papillomavirus infection by type and human immunodeficiency virus serostatus," International Journal of Cancer, vol. 119, no. 7, pp. 1623-1629, 2006.

[310] A. De Jong, M. I. E. Van Poelgeest, J. M. Van Der Hulst et al., "Human papillomavirus type 16-positive cervical cancer is associated with impaired $\mathrm{CD}^{4+} \mathrm{T}$-cell immunity against early antigens E2 and E6," Cancer Research, vol. 64, no. 15, pp. 54495455, 2004.

[311] J. S. Smith, S. Moses, M. G. Hudgens et al., "Increased risk of HIV acquisition among Kenyan men with human papillomavirus infection," Journal of Infectious Diseases, vol. 201, no. 11, pp. 1677-1685, 2010.

[312] M. Scott, M. Nakagawa, and A.-B. Moscicki, "Cell-mediated immune response to human papillomavirus infection," Clinical and Diagnostic Laboratory Immunology, vol. 8, no. 2, pp. 209220, 2001.

[313] S. H. Averbach, P. E. Gravitt, R. G. Nowak et al., "The association between cervical human papillomavirus infection and HIV acquisition among women in Zimbabwe," AIDS, vol. 24, no. 7, pp. 1035-1042, 2010.

[314] J. Laurson, S. Khan, R. Chung, K. Cross, and K. Raj, "Epigenetic repression of E-cadherin by human papillomavirus 16 E7 protein," Carcinogenesis, vol. 31, no. 5, pp. 918-926, 2010.

[315] J. Palefsky, "Human papillomavirus-related tumors in HIV," Current Opinion in Oncology, vol. 18, no. 5, pp. 463-468, 2006.

[316] T. D. Feola, M. B. Albert, K. Shahabi, and T. Endy, "Prevalence of HPV in HIV-infected women in the designated AIDS center at upstate medical university and the potential benefit of vaccination regardless of age," Journal of the Association of Nurses in AIDS Care, vol. 24, no. 2, pp. 176-179, 2013. 


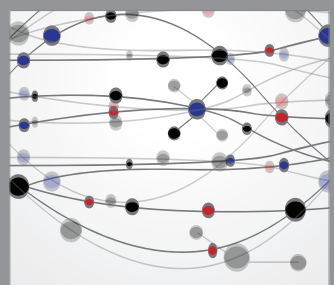

The Scientific World Journal
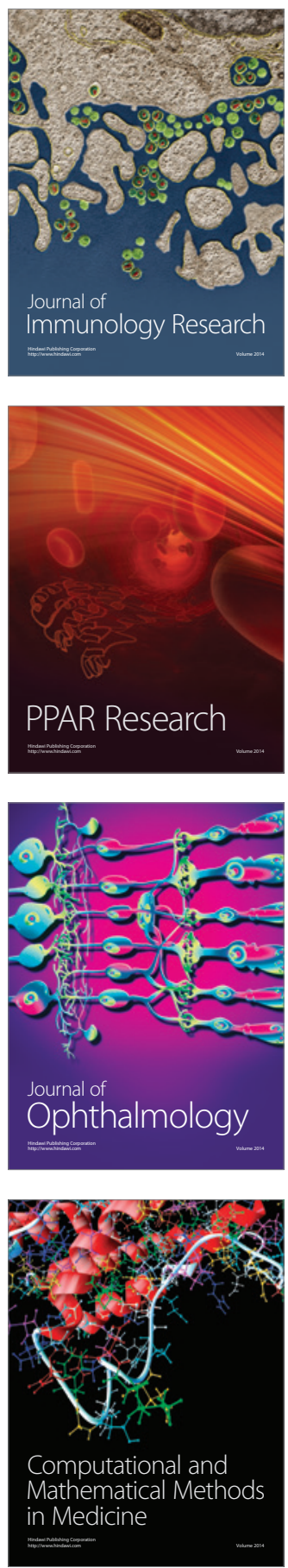

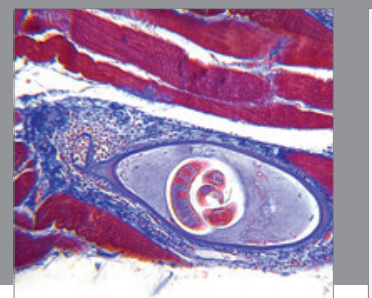

Gastroenterology

Research and Practice
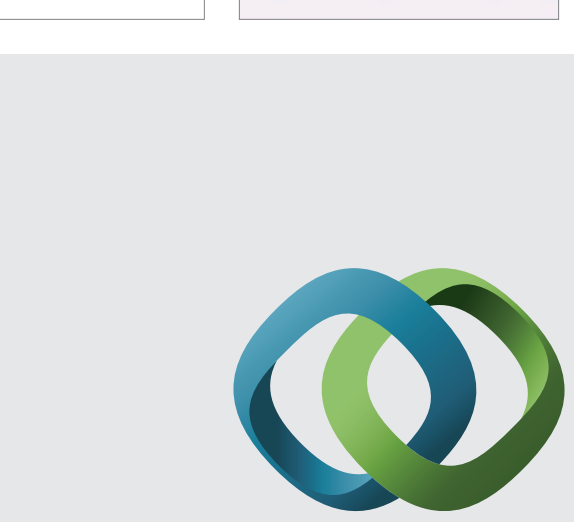

\section{Hindawi}

Submit your manuscripts at

http://www.hindawi.com
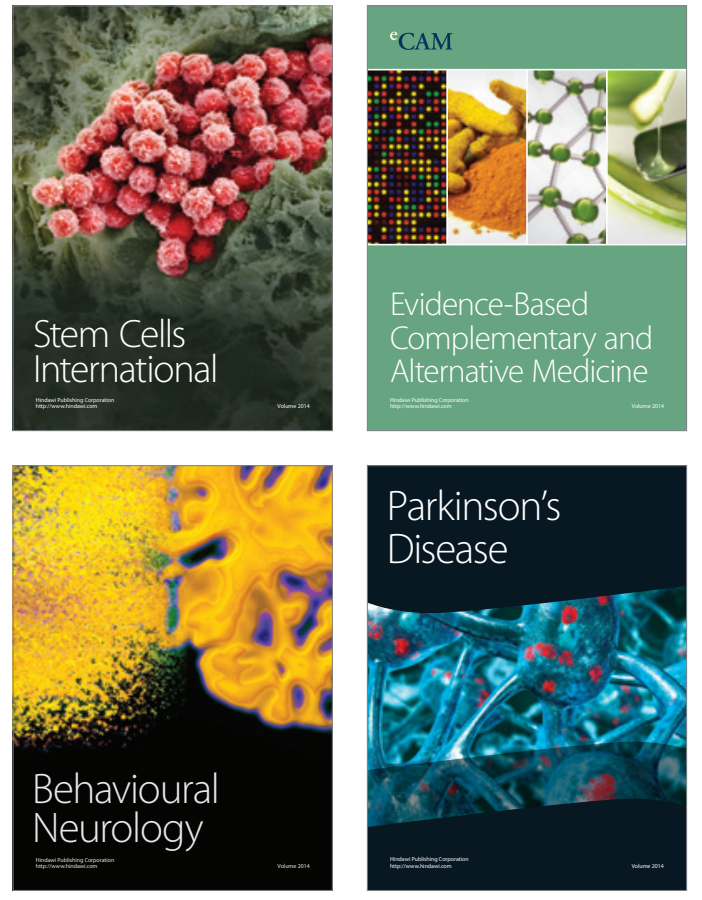
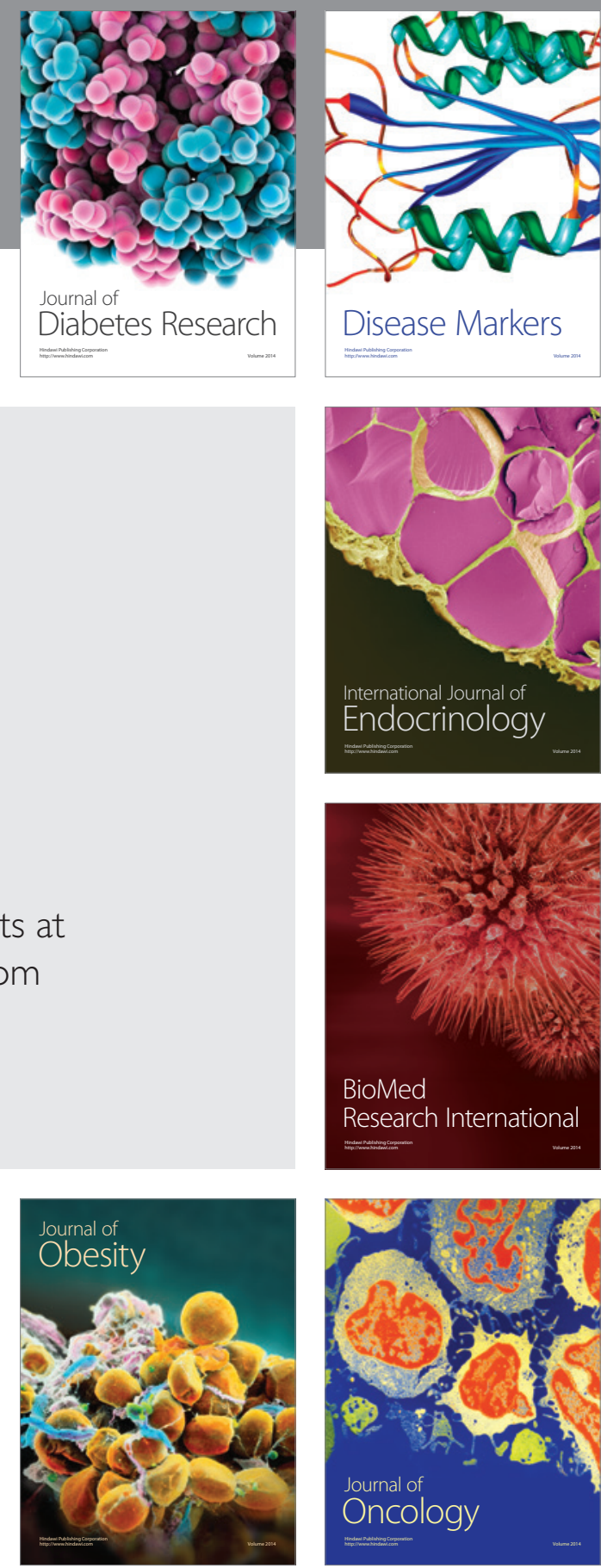

Disease Markers
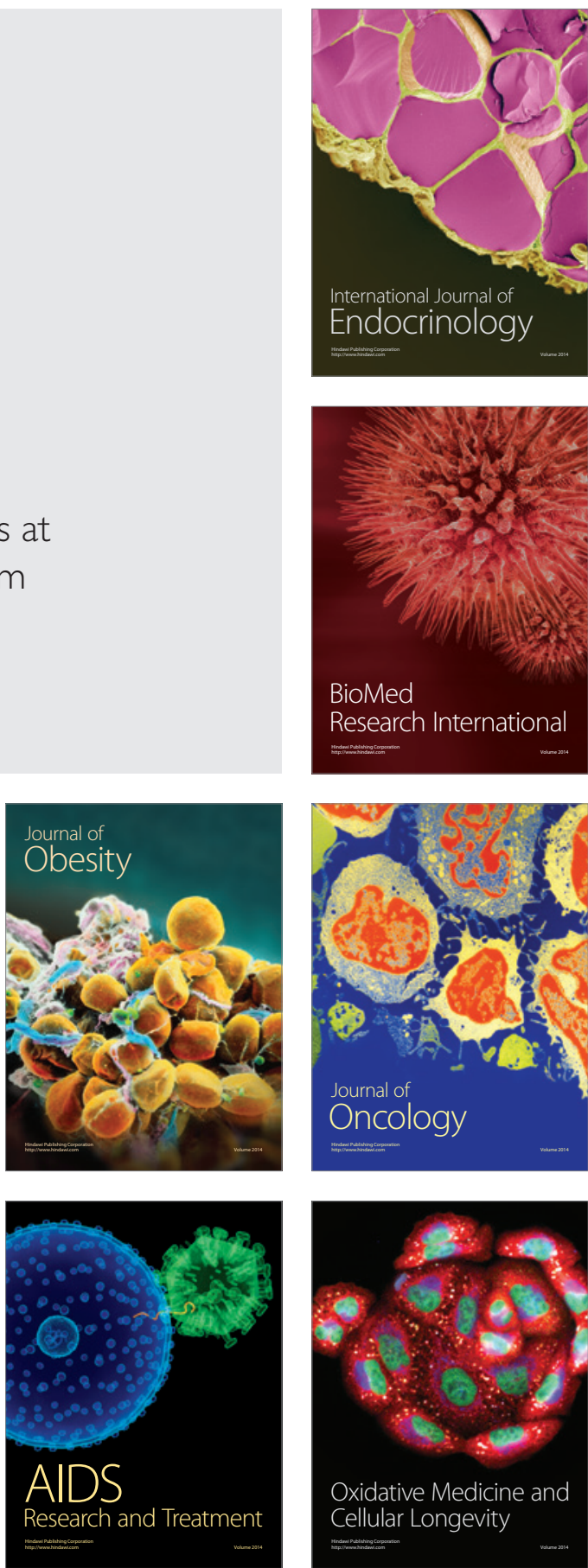